\title{
Variability of carbonaceous aerosols in remote, rural, urban and industrial environments in Spain: implications for air quality policy
}

\author{
X. Querol ${ }^{1}$, A. Alastuey ${ }^{1}$, M. Viana ${ }^{1}$, T. Moreno ${ }^{1}$, C. Reche $^{1}$, M. C. Minguillón ${ }^{1}$, A. Ripoll ${ }^{1}$, M. Pandolfi ${ }^{1}$, F. Amato ${ }^{1}$, \\ A. Karanasiou ${ }^{1}$, N. Pérez ${ }^{1}$, J. Pey ${ }^{1}$, M. Cusack ${ }^{1}$, R. Vázquez ${ }^{1}$, F. Plana ${ }^{1}$, M. Dall'Osto ${ }^{1}$, J. de la Rosa ${ }^{2}$, A. Sánchez de \\ la Campa ${ }^{2}$, R. Fernández-Camacho ${ }^{2}$, S. Rodríguez ${ }^{3}$, C. Pio ${ }^{4}$, L. Alados-Arboledas ${ }^{5}$, G. Titos ${ }^{5}$, B. Artínano ${ }^{6}$, \\ P. Salvador ${ }^{6}$, S. García Dos Santos ${ }^{7}$, and R. Fernández Patier ${ }^{7}$ \\ ${ }^{1}$ Institute of Environmental Assessment and Water Research, IDAEA, CSIC, Barcelona, Spain \\ ${ }^{2}$ Associate Unit CSIC - University of Huelva "Atmospheric Pollution”, Center for Research in Sustainable Chemistry \\ (CIQSO), University of Huelva, Huelva, Spain \\ ${ }^{3}$ Centro de Investigación Atmosférica de Izaña (CIAI) de AEMET, Associate Unit CSIC-AEMET "Atmospheric Pollution", \\ Santa Cruz de Tenerife, Tenerife, Spain \\ ${ }^{4}$ CESAM, Department of Environment, University of Aveiro, Aveiro, Portugal \\ ${ }^{5}$ Departamento de Física Aplicada and Centro Andaluz de Medio Ambiente (CEAMA), Universidad de Granada, \\ Granada, Spain \\ ${ }^{6}$ CIEMAT, Associate Unit CSIC-CIEMAT “Atmospheric Pollution”, Madrid, Spain \\ ${ }^{7}$ Instituto de Salud Carlos III, Madrid, Spain \\ Correspondence to: X. Querol (xavier.querol@idaea.csic.es)
}

Received: 19 December 2012 - Published in Atmos. Chem. Phys. Discuss.: 15 March 2013

Revised: 22 May 2013 - Accepted: 24 May 2013 - Published: 1 July 2013

\begin{abstract}
We interpret here the variability of levels of carbonaceous aerosols based on a 12 yr database from 78 monitoring stations across Spain specially compiled for this article. Data did not evidence any spatial trends of carbonaceous aerosols across the country. Conversely, results show marked differences in average concentrations from the cleanest, most remote sites (around $1 \mu \mathrm{g} \mathrm{m}^{-3}$ of non-mineral carbon (nmC), mostly made of organic carbon (OC) with very little elemental carbon (EC), around $0.1 \mu \mathrm{g} \mathrm{m}^{-3}$; OC/EC $=12-15$ ), to the highly polluted major cities $\left(8-10 \mu \mathrm{g} \mathrm{m}^{-3}\right.$ of $\mathrm{nmC} ; 3-$ $4 \mu \mathrm{g} \mathrm{m}^{-3}$ of EC; $4-5 \mu \mathrm{g} \mathrm{m}^{-3}$ of OC; OC /EC $=1-2$ ). Thus, urban (and very specific industrial) pollution was found to markedly increase levels of carbonaceous aerosols in Spain, with much lower impact of biomass burning and of biogenic emissions. Correlations between yearly averaged OC/EC and $\mathrm{EC}$ concentrations adjust very well to a potential equation $\left(\mathrm{OC}=3.37 \mathrm{EC}^{0.326}, R^{2}=0.8\right)$. A similar equation is obtained when including average concentrations obtained at other European sites $\left(\mathrm{OC}=3.60 \mathrm{EC}^{0.491}, R^{2}=0.7\right)$.

A clear seasonal variability in $\mathrm{OC}$ and $\mathrm{EC}$ concentrations was detected. Both $\mathrm{OC}$ and EC concentrations were higher
\end{abstract}

during winter at the traffic and urban sites, but OC increased during the warmer months at the rural sites. Hourly equivalent black carbon (EBC) concentrations at urban sites accurately depict road traffic contributions, varying with distance from road, traffic volume and density, mixing-layer height and wind speed. Weekday urban rush-hour EBC peaks are mimicked by concentrations of primary gaseous emissions from road traffic, whereas a single midday peak is characteristic of remote and rural sites. Decreasing annual trends for carbonaceous aerosols were observed between 1999 and 2011 at a large number of stations, probably reflecting the impact of the EURO4 and EURO5 standards in reducing the diesel PM emissions. This has resulted in some cases in an increasing trend for $\mathrm{NO}_{2} /(\mathrm{OC}+\mathrm{EC})$ ratios as these standards have been much less effective for the abatement of $\mathrm{NO}_{x}$ exhaust emissions in passenger diesel cars. This study concludes that $\mathrm{EC}, \mathrm{EBC}$, and especially $\mathrm{nmC}$ and $\mathrm{OC}+\mathrm{EC}$ are very good candidates for new air quality standards since they cover both emission impact and health-related issues. 


\section{Introduction}

Carbonaceous material typically accounts for 10 to $50 \%$ of the total particulate matter $\left(\mathrm{PM}_{10}\right)$ mass concentration (Putaud et al., 2010). Particulate carbon may be classified into three components: organic carbon (OC), elemental carbon (EC, sometimes used as an equivalent to black carbon, $\mathrm{BC}$ ) and carbonate or mineral carbon (CC). The term nonmineral carbon $(\mathrm{nmC})$ is used for the concentrations of total carbon once $\mathrm{CC}$ has been subtracted. OC can be of both primary and secondary origin, i.e. emitted directly into the atmosphere or formed by the condensation of compounds produced in the atmosphere by photo-oxidation of volatile organic precursors (Fuzzi et al., 2006). In contrast, EC is exclusively of primary origin (incomplete combustion of carboncontaining fuels, and to a lesser extent brake wear). CC is another primary carbonacous species and is present in natural dust as well as in urban dust.

Most of the carbonaceous PM present in the atmosphere arises from fuel combustion (fossil or not), industrial processes and biogenic emissions (both primary and secondary), depending on the monitored environment (Jimenez et al., 2009). Soil and road/urban dust particles may also contribute with significant fractions to the carbon load in PM.

In recent years scientific research has focused on carbonaceous particles due to their impact on climate and human health (Ramana et al., 2010; Shindell et al., 2012). Carbonaceous aerosols contribute substantially to the absorption and scattering of radiation in the troposphere and cause direct radiative forcing; for example, $\mathrm{BC}$ absorbs sunlight, thus heating the atmosphere, whereas most organic aerosol components have the opposite effect (Kanakidou et al., 2005; Ramanathan and Carmichael, 2008). A number of studies strongly suggest a link between carbonaceous aerosols and health effects of airborne particles. EC concentrations have been used as a surrogate for exposure to diesel exhaust (Birch and Cary, 1996), with these emissions enhancing immunological responses to allergens and eliciting inflammatory reactions with impact on the respiratory and cardiovascular systems at relatively low concentrations and short exposure durations (Brunekreef et al., 1997). Organic aerosols may also pose a significant risk to human health (Mauderly and Chow, 2008; Verma et al., 2009).

According to previous studies (Querol et al., 2008) nmC in Spain accounts for $10-22 \%$ of $\mathrm{PM}_{10}$ in the rural background, $10-27 \%$ in the urban background and $20-32 \%$ at traffic/kerbside sites. These percentages increase to 25-28\% (rural), 21-37\% (urban) and 32-42\% (kerbside) in $\mathrm{PM}_{2.5}$. These concentration ranges are very similar to those reported for the whole of Europe (Putaud et al., 2010), with a probable lower percentage of EC in PMx in southern Europe versus central Europe.

Despite the very large proportion of carbonaceous aerosols in PMx and the consequent relevance of this component for air quality plans to abate ambient PMx levels, their origins are not fully understood (Volkamer et al., 2006; Robinson et al., 2007; Jimenez et al., 2009), and probably their contribution to PMx load vary largely across the different regions in Europe (European Integrated Project on Aerosol Cloud Climate and Air Quality Interactions, EUCAARI, Kulmala et al., 2011; Alves et al., 2012). Thus, although it is generally accepted that vehicles' diesel engines contribute to increase primary carbonaceous components in urban agglomerations, there is also important evidence of biomass burning from domestic heating highly contributing to this increase in central, northern, Atlantic and eastern Europe (Alves et al., 2012), but at less extent in southern Europe. Furthermore, the interaction of volatile organic compounds (VOCs) from traffic and biogenic origins with $\mathrm{NO}_{\mathrm{x}}$ and $\mathrm{O}_{3}$ may result in the production of significant amounts of secondary organic aerosols (SOA) that contribute to a large fraction of OC (Jimenez et al., 2009). Cooking has also been detected by contribute in significant amounts to increasing OC levels in urban areas (Mohr et al., 2012).

Although laboratory experiments have shown that organic compounds in exhaust from both petrol and diesel engines can form SOA, the fractional contribution from petrol and diesel exhaust emissions to ambient SOA in urban environments is poorly known. Recently Bahreini et al. (2012) demonstrated that in Los Angeles the contribution from petrol emissions dominates over diesel regarding the formation of SOA. Chamber studies performed in Europe seem to confirm this hypothesis (Platt et al., 2012) with these results having important implications for air quality policy. Verma et al. (2009) have also shown for Los Angeles that both primary and secondary particles in summer possess high redox activity; however, photochemical transformations of primary emissions during atmospheric aging enhance the toxicological potency of secondary particles in terms of generating oxidative stress and leading to subsequent cell damage.

The above discussions indicate that the origin of OC, especially of SOA, is a hot topic in atmospheric sciences. Thus, Minguillón et al. (2011) reported that even for the high traffic density city of Barcelona, $60 \%$ of $\mathrm{OC}\left(\mathrm{PM}_{1}\right)$ urban background collected during 1 month (March 2009) arises from non-fossil C sources. Furthermore, a recent WHO report (REVIHAAP report, WHO, 2013) indicates that further studies are needed to characterize the health effects of SOA, although some results, as stated above, evidence health outcomes of these aerosol components. Another recent WHO report (WHO, 2012) also evidences clear health consequences from the increased concentrations of $\mathrm{BC}$, although this is probably not due to EC per se but to the OC compounds that EC particles carry on.

The OC/EC ratios from different combustion sources may also widely vary. Thus, a typical ratio OC / EC reaches values lower than 0.5 for diesel emissions (Zielinska et al, 2004; El Haddad et al, 2009) and 0.75 in road tunnel studies (Pio et al., 2011). However, an average ratio of 3.3 has been calculated by Minguillón et al. (2011) for biomass burning emissions, 
based on the reported values for common biofuel species in the Mediterranean (with similar combustion methods to those used in Spain; Fine et al., 2004; Gonçalves et al., 2010), and agricultural fires (Chow et al., 2010a).

We would also like to highlight that the relative contributions to ambient levels of carbonaceous aerosols may change not only spatially across Europe but also in time for a given location. Thus, it is clear that the EURO4 (implemented since 2005) and EURO5 (2009) requirements have decreased diesel exhaust emissions, and consequently may have reduced EC emissions, especially in urban areas. On the other hand, the current financial crisis in Europe may drive some regions to increase the use of biomass fuels for domestic heating (e.g.http://phys.org/news/ 2012-12-wood-burning-pollution-alarm-bells-athens.html).

The current evaluation of the European air quality policy has to take into account the above issues, among others, in order to technically select cost-effective abatement measures to improve air quality.

This work focuses on the characteristics, trends and sources of carbonaceous aerosols in urban, traffic, industrial, rural and remote sites in Spain (western Mediterranean). The objectives of this study are to interpret the temporal and spatial variability of ambient air concentrations of particulate $\mathrm{nmC}, \mathrm{OC}, \mathrm{EC}$ and $\mathrm{EBC}$ across Spain. To this end, data obtained with similar methods at 78 monitoring sites across the country during the period 1999-2011 were compiled and interpreted. We focus on the following: (a) mean concentration ranges for $\mathrm{nmC}, \mathrm{OC}, \mathrm{EC}$ and $\mathrm{EBC}$; (b) inter-annual and seasonal trends; (c) OC/EC ratios; (d) EBC/EC ratios; and (e) possible origins for OC and EC. Finally, we discuss the feasibility and usefulness of measuring and regulating the concentrations of these compounds.

\section{Methodology}

\subsection{Sampling}

During the period 1999-2011 nmC concentrations were determined at 78 monitoring stations across mainland Spain, the Balearic and Canary archipelagos and the Spanish northern African territories (Fig. 1 and Table 1). OC and EC concentrations were available for 33 sites. The analyses were carried out in $\mathrm{PM}_{10}$ and $\mathrm{PM}_{2.5} 24 \mathrm{~h}$ samples. Table 1 shows the $\mathrm{nmC}, \mathrm{OC}, \mathrm{EC}$ and $\mathrm{EBC}$ mean concentrations for specific periods (in most cases covering $>1 \mathrm{yr}$ ) in the following sites:

- Two remote sites including Montsec in the NE of the Iberian Peninsula (IP) and Izaña on the Canary Islands.

- Ten rural/regional background sites on the IP and the Balearic Islands, including Montseny, Monagrega, Bemantes and El Perdón in the N of IP; Cortijo Endrinales, and San Jorge in central IP; Matalascañas, Valverde and

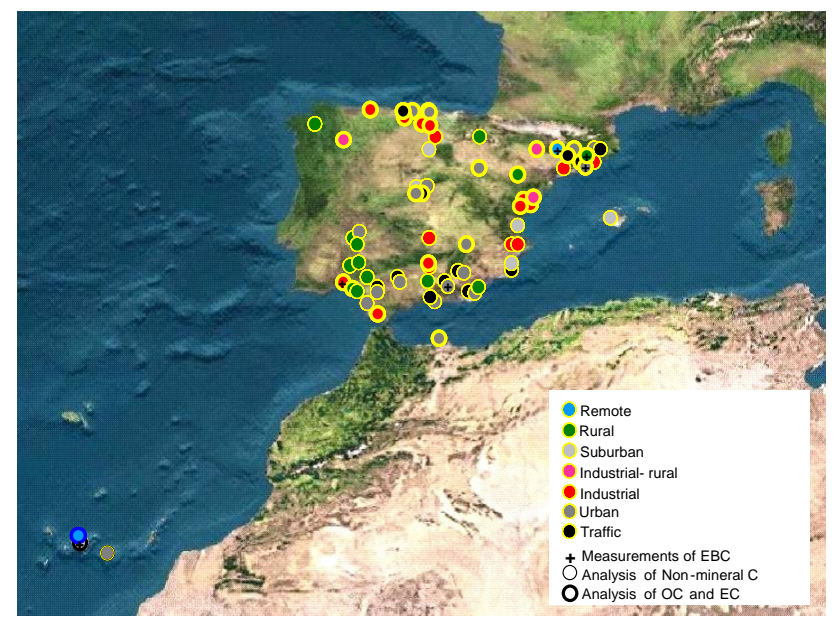

Fig. 1. Location of the monitoring stations across mainland Spain, the Balearic and Canary Archipelagoes and the Spanish northern African territories from where data on $\mathrm{nmC}, \mathrm{OC}, \mathrm{EC}$ and $\mathrm{EBC}$ were obtained during the period 1999-2011.

Campillos in the SW of IP; and Can Llompart on the Balearic Islands.

- Ten industrial-rural or industrial-suburban sites including Ponferrada, Plaza Castillo-Almeria and PobladoCórdoba (all three with power generation) in the $\mathrm{N}$ and $\mathrm{S}$ of IP; Torrelavega (chemical industry) in the $\mathrm{N}$ of IP; Monzón (metal and agro-industry) in the NE of IP; Alacant (cement manufacturing) in the E of IP; Onda, influenced by ceramic and glass manufacture emissions form a large industrial estate in the E of IP; Arenosillo (metallurgy, petrochemical plants and fertilizers) and Punta Umbria (metallurgy and fertilizers) in the SW of IP; and Santa Cruz (shipping and petrochemical emissions) on the Canary Islands.

- Twenty industrial urban sites including Tarragona, Puertollano (both with large chemical and petrochemical estates), Huelva, La Línea, Puente Mayorga and Los Barrios (with petrochemical and metallurgical estates, and shipping emissions), Bailén (manufacture of bricks and pottery), and Alcalá de Guadaira (smelter), all in the S of IP; L'Alcora, Vila-real, Borriana, Almassora and Agost (influenced by the ceramic and glass manufacture emissions) in the E of IP; Llodio, Bajo Cadagua and Zabalgarbi (metallurgy), Alsasua (cement manufacturing) and Avilés (coke production) in the N of IP; and Torredonjimeno and Montcada (cement production) in $\mathrm{S}$ and NE Spain, respectively.

- Seven suburban sites including Palma de Mallorca (Balearic Islands), Chapineria (central IP), Burgos (central-N IP), Badajoz (central-SW IP), Santa AnaCartagena (SE IP), El Vacar-Córdoba (central-S IP), 
Nerva-Huelva (SW IP). These are stations located in the outskirts of towns or villages.

- Nineteen urban background sites, including Granada, Moguer, Cádiz, Córdoba, Sevilla and Jaén in the S of IP; Melilla in N Africa; Las Palmas de Gran Canaria on the Canary Islands; Albacete in the SE of IP; Alcobendas and Madrid in central IP; Barcelona, Sabadell, Girona, and Zaragoza in NE of IP; and two sites in Bilbao, one site in Pamplona and one in Santander in the N of IP.

- Ten road traffic sites in Sabadell, Girona and Barcelona (in NE of IP); Madrid (central IP); Granada, Almería, Málaga-Carranque (S of IP); Cartagena (SE of IP); Barreda-Torrelavega, Pamplona and Bilbao (N of IP).

For the categorization of urban background, traffic and industrial sites, we used the same category as the one used for the Spanish air quality data repository that follows the criteria of classification by Larssen et al. (1999). This uses a combination of the following:

- Type of station: traffic, industrial, background.

- Type of zone: urban, suburban, rural.

Total carbon, OC and EC measurements were carried out on $\mathrm{PM}_{\mathrm{x}}$ samples collected on filters by high- or low-volume samplers. To this end, microfibre quartz filters from different brands were used during the period 1999-2011 - including Schleicher and Schuell, Munktell and Pallflex - after a $200^{\circ} \mathrm{C}$ treatment, with the only exception being for the monitoring site in Madrid where online techniques were applied for OC and EC measurements. The online EBC measurements were carried out at six sites (Barcelona, Huelva, Santa Cruz, Granada, Montseny and Montsec).

\section{2 nmC determinations}

The $\mathrm{nmC}$ contents were obtained by subtracting the mineral or carbonate carbon (CC) from the total carbon (total C) determined by means of classical elemental analysis. The total $\mathrm{C}$ was determined in a circular fraction (of $2.54 \mathrm{~cm}$ diameter) of the corresponding $\mathrm{PM}_{\mathrm{x}}$ filter with elemental analysers using a few milligrams of $\mathrm{V}_{2} \mathrm{O}_{5}$ as an oxidant agent. The $\mathrm{CC}$ was stoichiometrically obtained from the $\mathrm{Ca}$ and $\mathrm{Mg}$ concentrations determined in the same filters by assuming that these two elements are present as calcite and/or dolomite $\left(\mathrm{CaCO}_{3}\right.$ and $\left.\mathrm{CaMg}\left(\mathrm{CO}_{3}\right)_{2}\right)$. $\mathrm{Ca}$ and $\mathrm{Mg}$ may be present in mineral dust in forms other than calcite and dolomite; for example, a small fraction of $\mathrm{Ca}$ in soils may be present in aluminium silicates, such as anorthite (which does not contain carbonate), and $\mathrm{Mg}$ can have a minor sea salt origin and may be supplied also by some clay minerals. But in both cases these contributions are lower than the one from carbonate minerals. Furthermore, even in the case that dust soil particles are emitted as carbonates, inter-reaction in the atmosphere with
$\mathrm{SO}_{2}, \mathrm{H}_{2} \mathrm{SO}_{4}$ and $\mathrm{HNO}_{3}$ has a tendency to transform those into sulfate and nitrate species. Therefore, the use of $\mathrm{Ca}$ and $\mathrm{Mg}$ as tracers may result in an underestimation of $\mathrm{nmC} \mathrm{lev-}$ els, but, in any case, mean CC concentrations were generally low (e.g. 9 and $2 \%$ of total $\mathrm{C}$ in $\mathrm{PM}_{10}$ and $\mathrm{PM}_{2.5}$, respectively, in Barcelona). The recovery, detection limit (around $0.1 \mu \mathrm{g} \mathrm{m}^{-3}$ if high-volume samplers are used) and uncertainties of the method are the typical for elemental analysers. When only a thermal-optical method was used for the analysis of the carbonaceous aerosols, $\mathrm{nmC}$ was obtained as the sum $\mathrm{OC}+\mathrm{EC}$, without any subtraction of CC.

\subsection{EC and OC determinations}

Concentrations of $\mathrm{OC}$ and $\mathrm{EC}$ were determined on the $\mathrm{PM}_{\mathrm{X}}$ filters by the thermal-optical transmission method (TOT).

Filters from Monagrega and Barcelona-traffic in 1999-2000, as well as from Huelva, Arenosillo, La Línea and Bailén in the period June 2005-June 2006, were analysed in the laboratories of Aveiro University using the TOT protocol described by Pio et al. (1994). The method consists of a quartz tube with two heating zones, a laser and a detector for the laser beam, and a $\mathrm{CO}_{2}$ analyser. A circular section of $9 \mathrm{~mm}$ in diameter of the sampled quartz filter is placed vertically inside a quartz tube oven and heated to $600{ }^{\circ} \mathrm{C}$ in a nitrogen atmosphere to vaporize organic carbon. A second heating zone is filled with cupric oxide and maintained at $650{ }^{\circ} \mathrm{C}$ during the entire analysis process to guarantee the total oxidation of the volatilized carbon to $\mathrm{CO}_{2}$, which is analysed by a non-dispersive infrared detector (NDIR). Controlled heating is used in steps to separate OC into four fractions of increasing volatility of lower and higher molecular weight organics, as follows: step1 $\left(T \leq 150^{\circ} \mathrm{C}\right.$, OC 1$)$; step $2\left(T \leq 150-350{ }^{\circ} \mathrm{C}\right.$, OC 2$)$; and step3 $\left(T \leq 350-600^{\circ} \mathrm{C}\right.$, OC 3$)$. Elemental carbon is determined by sequential heating at $850^{\circ} \mathrm{C}$ in a nitrogen and air atmosphere (step4). A laser beam is used to differentiate between OC and EC, based on filter light transmittance, similar to other thermal-optical methods. Intercomparison data showed that the Aveiro University methodology correlates very well with the EUSAAR2 protocol (Supplement, Fig. S2).

The remaining filter samples were analysed using TOT Sunset Laboratory instruments at the IDAEA-CSIC laboratory in Barcelona and the Carlos III Health Institute in Madrid, from 2007 to present. A NIOSH-like thermal protocol adequate for the offline Sunset analyser (known as Quartz.par) was used in an initial phase, whereas the EUSAAR2 protocol was used from July 2008 onwards. Only OCEC data from Barcelona for years 2004-2006 were obtained using a Sunset OCEC analyser at Ghent University using also the Quartz protocol (Viana et al., 2006). The Quartz protocol is a NIOSH-like protocol as described in the European guide CEN/TR 16243:2011, and it is widely used by researchers (e.g. Schmid et al., 2001; Schauer et al., 2003; 


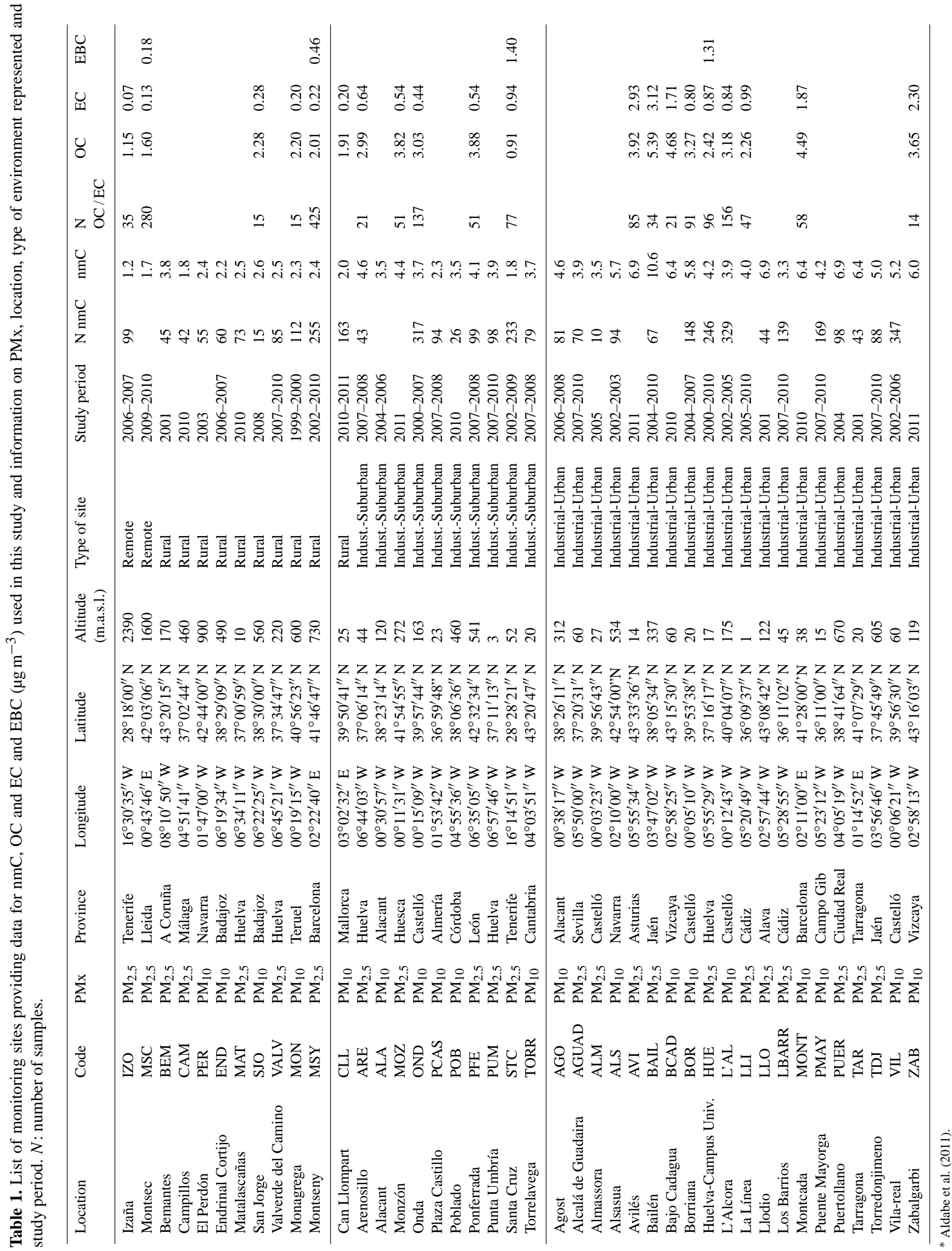




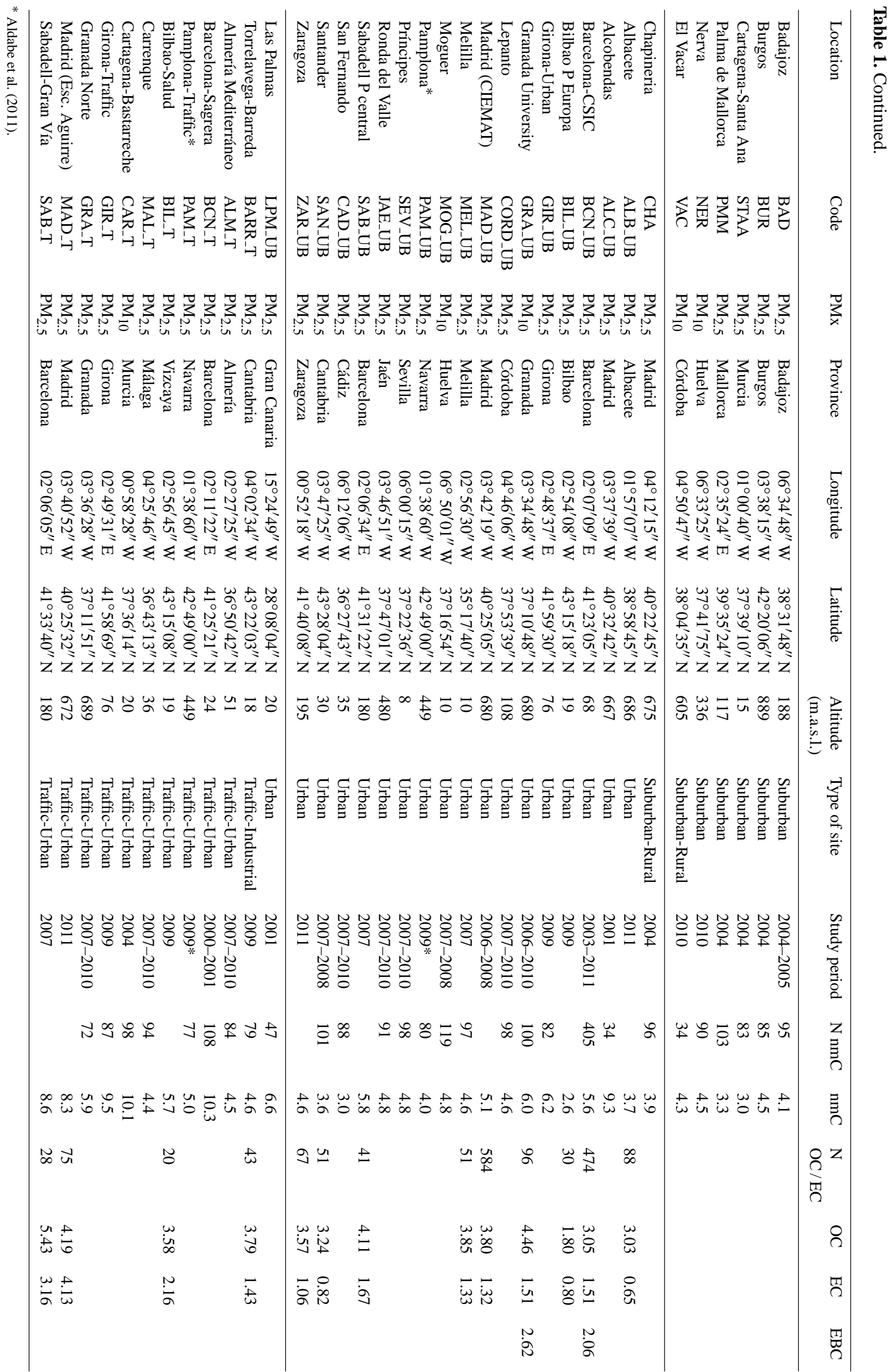


Viana et al., 2007; Koulouri et al., 2008; Bae et al., 2004). It is the protocol of a subsequent version provided by the instrument's manufacturer (Birch and Cary, 1996), and it is commonly referred to in the literature as modified "NIOSH" protocol, being directly comparable to the NIOSH 5040 or NIOSH/EPA thermal protocols (Cavalli et al., 2010).

For the TOT method with the Sunset analysers (Birch and Cary, 1996), a punch (typically $1.5 \mathrm{~cm}^{2}$ ) of a quartz fibre filter sample is placed in the quartz oven of the instrument. In the initial phase of the analysis, which takes place in a pure He gas stream, the filter punch is heated in different series of steps (according to the different temperature protocols), the desorbed carbonaceous vapours are catalytically oxidized into $\mathrm{CO}_{2}$ (by a $\mathrm{MnO}_{2}$ catalyst), which is then transformed into $\mathrm{CH}_{4}$ (in a Ni-firebrick methanator oven) and subsequently measured with a flame ionization detector (FID). Laser light of $670 \mathrm{~nm}$ is passed through the filter punch and the light transmission is continuously measured in order to correct for pyrolysed OC. In the second phase, which takes place with a $98 \% \mathrm{He} / 2 \% \mathrm{O}_{2}$ mixture as carrier gas, the filter punch is further heated, and the $\mathrm{CO}_{2}$ evolved is measured by FID in the form of $\mathrm{CH}_{4}$ (as in the first phase). When the light transmission through the filter punch equals that seen at the beginning of the first phase, the $\mathrm{OC} / \mathrm{EC}$ split is set to correct for pyrolytic carbon (PC): the $\mathrm{CO}_{2}$ measured in the first phase and during the second phase prior to the split is considered OC (including the PC), whereas the $\mathrm{CO}_{2}$ measured after the split is considered the "original" EC. After the end of the second phase, while still in a $\mathrm{He} / \mathrm{O}_{2}$ mixture, a known amount of $\mathrm{CH}_{4}$ gas is injected through a loop for internal calibration. The Quartz and the EUSAAR2 thermal protocols are described in Table S1.

Finally, EC and OC at the urban background site in Madrid were determined on a semi-continuous basis by a thermal analyser (ambient carbonaceous particle monitor - ACPM, Rupprecht and Patashnick model 5400, Thermo Scientific Inc.). This online analyser collects $\mathrm{PM}_{2.5}$ onto an impactor plate prior to the sequential heating/oxidation. $\mathrm{CO}_{2}$ concentrations from this oxidation are analysed online. Two sequential heating/combustion steps, at $340^{\circ} \mathrm{C}$ and $750{ }^{\circ} \mathrm{C}$, are used to separate and determine OC and EC fractions, respectively. The use of ambient air as oxidant for both carbonaceous fractions minimizes the pyrolysis of $\mathrm{OC}$, thus avoiding the need to apply charring correction factors. The instrument has been compared with results of collocated filter sampling and subsequent offline TOT analysis at Aveiro University and data were corrected according to the results of this comparison (Plaza et al., 2011).

The assessment of the comparability between the different thermal protocols used is not the objective of the present work as numerous studies have already addressed it (Cavalli et al., 2010; Subramanian et al., 2006; Chow et al., 2001, 2004; Conny et al., 2003; Schauer et al., 2003; Schmid et al., 2001). In Europe mainly the EUSAAR2 and NIOSH protocols are used. The authors are aware that this is a limitation of the study, which is accounted for in the discussion (see sections below). The scope of the paper is to report and discuss the characteristics, trends and sources of carbonaceous aerosols from long-term measurements across Spain.

\subsection{Online EBC measurements}

Hourly EBC concentrations (at $\lambda=637 \mathrm{~nm}$ ) were measured for at least one year at the 6 sites shown in Table 1 by means of a multi-angle absorption photometer (MAAP, model 5012 Thermo Scientific). The EBC concentration provided by MAAP is calculated by the instrument's software as EBC $\left[\mathrm{g} \mathrm{m}^{-3}\right]=\sigma_{\mathrm{ap}}(\lambda)\left[\mathrm{m}^{-1}\right] / \sigma(\lambda)\left[\mathrm{m}^{2} \mathrm{~g}^{-1}\right]$ (Petzold and Schönlinner, 2004), where $\sigma_{\mathrm{ap}}(\lambda)$ is the measured absorption coefficient and $\sigma(\lambda)$ is the mass absorption cross section (MAC). The default MAC used by the instrument is $6.6 \mathrm{~m}^{2} \mathrm{~g}^{-1}$, which is the MAC at $637 \mathrm{~nm}$ (Müller et al., 2011) recommended by the manufacturer.

The values of MAC may vary as a function of the aerosol composition and age, and therefore they can differ depending on the area under study and meteorological scenarios. Mass absorption cross sections (MAC) between $7 \mathrm{~m}^{2} \mathrm{~g}^{-1}$ and $15 \mathrm{~m}^{2} \mathrm{~g}^{-1}$ have been usually reported in the literature (e.g. Bond and Bergstrom, 2006; Fernández-Camacho et al., 2010; He et al., 2009; Barnard et al., 2008; Arnott et al., 2003, 2005; Reche et al., 2011). MACs obtained in the present study are shown in Fig. S1 as the slope of the regression equation between the absorption coefficient and the concentrations of EC determined from filters by the thermal-optical method. Results evidenced MACs around $10 \mathrm{~m}^{2} \mathrm{~g}^{-1}$ in urban and rural sites, showing a higher variation in remote locations.

Nevertheless, in order to facilitate comparison with measurements recorded at other areas, the EBC concentrations shown in the present paper are those directly provided by the MAAP instruments (i.e. after applying a default value of $6.6 \mathrm{~m}^{2} \mathrm{~g}^{-1}$ ). Thus, according to the above MACs values, EBC data here presented may be overestimated by $30-35 \%$.

\subsection{Limitations of the methods used}

Real-time BC measurements are performed by using optical methods which measure the attenuation of light through a filter collecting airborne particles. The more commonly used instrumentation includes the aethalometer (Magee Scientific, Berkeley, USA, Hansen et al., 1984), the particle soot absorption photometer, PSAP (Bond et al., 1999) and the multi-angle absorption photometer, MAAP (Petzold and Schönlinner, 2004). Despite intensive efforts over the last decades, no widely accepted standard measurement method exists for the determination of $\mathrm{BC}$ or light-absorbing carbon, although several intercomparisons have been carried out (Chow et al., 2009; Müller et al., 2011). Following suggestions by the GAW Scientific Advisory Group (GAW/WMO, 2011), the term "equivalent black carbon" (EBC) should be 
used instead of black carbon for measurements derived from optical methods. Much care must be taken when deriving EBC from light-absorption measurements, and the conversion factors used should be always supplied with the data (see prior Sect. 2.4).

Thermal-optical analysis has been widely used for the determination of $\mathrm{OC}$ and $\mathrm{EC}$ in atmospheric aerosol samples (Phuah et al., 2009). According to this method, OC desorbs in an inert atmosphere (He), while EC combusts in an oxidizing atmosphere (mixture of $\mathrm{He}$ and $\mathrm{O}_{2}$ ) at high temperature. However, some OC is pyrolytically converted to EC (char) when heated up in He. This process darkens the filter, and this darkening is used to correct for charring by continuously monitoring the transmittance (or reflectance) of the filter during the analysis (Birch and Cary, 1996). The more commonly employed thermal protocols are IMPROVE (Chow et al., 1993), NIOSH (Birch and Cary, 1996) and EUSAAR2 (Cavalli et al., 2010). Thermal-optical analysis can also be used for the determination of $\mathrm{CC}$ which is usually not considered in atmospheric studies. Recently Karanasiou et al. (2011) reported on the possibility of identifying and quantifying atmospheric CC using a thermal-optical transmission analyser.

Collecting particles on filters for offline or online thermaloptical analysis potentially leads to sampling artifacts. Positive OC artifacts arise from organic vapour adsorption onto quartz-fibre filter material and/or previously collected particles (matrix), leading to an overestimation of particulate OC (Turpin et al., 2000; Mader et al., 2001). Negative artifacts can be caused by volatilization of organic particlephase semi-volatile compounds from the filter into the gas phase, leading to an underestimation of OC (Subramanian et al., 2004; Arhami et al., 2006). As an example, in the Barcelona urban area, positive artifacts for OC account for $0.5-0.7 \mu \mathrm{g} \mathrm{m}^{-3}$, representing $11-16 \%$ of the bulk OC mass and $3 \%$ of the $\mathrm{PM}_{2.5}$ mass, being slightly higher in summer when compared to winter (Viana et al., 2006).

The results and discussions presented are subject to a number of limitations, some of which are intrinsic to the methodologies used and are well documented in the literature. Below we highlight the most relevant limiting factors.

- Not all measurements (neither sampling nor analytical) were conducted simultaneously at all the study locations. This implies that the results may not always be directly comparable.

- Not all thermal-optical analyses were carried out using the same temperature protocol: whereas a fraction of the analyses were carried out using Quartz (the NIOSHlike) protocol, the most recent ones used EUSAAR2 protocol. A recent intercomparison showed that the EUSAAR2 protocol systematically leads to lower EC values compared to the NIOSH-derived protocols (Maenhaut et al., 2012, conference presentation). In some cases, such as Barcelona and Montseny, two protocols have been used along the time series, and this may have influenced artificially time trends of OC and EC levels, but probably not much those of $\mathrm{OC}+\mathrm{EC}$ or nmC levels.

- The determination of OC and EC comprises an intrinsic degree of uncertainty arising from the selection (whether automatic or manual) of the split point (Cavalli et al., 2010). The split between OC and EC is temperature protocol dependent, and in addition it is highly sensitive to the morphology of the $\mathrm{C}$ peaks during the analysis. A slight shift of the split point may result, on occasions, in large changes in the $\mathrm{OC} / \mathrm{EC}$ ratio. As reported in Subramanian et al. (2006), $15 \mu \mathrm{g} \mathrm{cm}^{-2}$ as the EC loading on a filter is a limit for assessing good performance of the Sunset (TOT) instrument. When loadings are greater than $15 \mu \mathrm{g} \mathrm{cm}^{-2}$, the laser signal passing through the filter is so low that no signal modulation for higher EC loadings can be detected during the He phase, and no correction for pyrolysis can therefore be performed. As a result, exceeding the $15 \mu \mathrm{g} \mathrm{cm}^{-2}$ would have a direct impact on the OC/EC ratio. During our study, this limit was not exceeded. Furthermore, the presence of high concentrations of iron oxides (or other metal oxides) may act as a catalyst or oxygen donors during the He phase in the TOT analysis. Wang et al. (2010) evidenced that metals reduce the oxidation temperature of EC and enhance the charring of OC. The split point used to determine classification of EC vs. OC may thus be more dependent on changes in EC oxidation temperature than on charring. This artifact is protocol dependent; that is, their extent depends on the use of the NIOSH, IMPROVE or EUSAAR2 protocols (Chow et al., 2004). In the present study, only samples from the background site of Izaña may have been affected by this artifact.

- The presence of carbonates in the sample could lead to an overestimation of the OC when EUSAAR2 or NIOSH-like thermal protocols are used. In this study $\mathrm{CC}$ was not removed prior to the analysis by e.g. acidification with $\mathrm{HCl}$ or phosphoric acid. As a result $\mathrm{CC}$ might interfere with the determination of OC or EC, depending on the carbonate characteristics, and on the thermal protocol used (Karanasiou et al., 2011).

- Positive and negative sampling artifacts were not taken into account in the present study since neither denuders nor impregnated filter packs were used during sampling. In most cases, high-volume samplers were used in which the high face velocity $\left(74 \mathrm{~cm} \mathrm{~s}^{-1}\right.$, as opposed to $22 \mathrm{~cm} \mathrm{~s}^{-1}$ for low-volume samplers, Viana et al., 2006) minimized the impact of positive OC artifacts (Turpin et al., 2000). In any case, tests carried out with low-volume samplers in Ghent, Amsterdam and Barcelona (Viana et al., 2007) evidenced that positive sampling artifacts ranged from 5 to $7 \%$ of the OC concentration in Ghent to $11-16 \%$ in Barcelona. They also found that artifacts 
were most likely higher in southern than in western Europe, as a consequence of higher ambient temperatures and the enhanced emission of VOCs. This may also be applied to a Spanish scale, where an intense climate gradient occurs. Longer sampling periods and higher filter loads have a tendency to reduce OC-positive artifacts as a result of saturation of adsorbing active sites on quartz filter surfaces. On the other hand, long sampling periods are prone to interferences from atmospheric changing equilibrium conditions. Recently positive artifacts were estimated to account for $29 \%$ of total $\mathrm{C}$ at the regional background station of Montseny in the framework of the EUSAAR project (www.eusaar.net; unpublished data), but this was obtained by using low-volume samplers. A low proportion is expected in the urban areas due to higher absolute OC particulate levels (Maenhaut et al., 2001) and the use of high-volume samplers. In any case positive and negative sampling artifacts may have a different impact in urban or rural environments (Chow et al., 2010b).

- A major limitation of the discussion is that we may in some cases compare EC, OC, EBC and nmC from $\mathrm{PM}_{10}$ and $\mathrm{PM}_{2.5}$. This may not be completely accurate for OC and probably less significant for EC and EBC. Most of the data refers to $\mathrm{PM}_{2.5}$, and only include $\mathrm{PM}_{10}$ when the first is not available. Although we are aware that OC in $\mathrm{PM}_{2.5}$ may be lower than in $\mathrm{PM}_{10}$ we still included $\mathrm{PM}_{10}$ data with the aim of a higher spatial coverage.

Although we reported here few insights on possible uncertainty ranges for the results presented, a solid uncertainty calculation seems hardly feasible in the context of such high and unknown artifact influences and the use of different OC and EC analysis protocols. However, we may probably have underestimated in this study EC levels (not nmC or OC $+\mathrm{EC}$ ) with respect to the use of NIOSH OC/EC protocol since prior studies evidenced that EUSAAR2 protocol may underestimate EC yield by 9 to $31 \%$ with respect to this US protocol (Menhaut et al., 2012). Also as an indicator of the influence that the PM size may suppose on the OC/EC analysis, OC and EC mean annual levels decrease by 10 and $9 \%$, and 12 and $17 \%$, respectively, for Montseny and Barcelona, from $\mathrm{PM}_{10}$ to $\mathrm{PM}_{2.5}$.

\subsection{Temporal trends}

Temporal trends were analysed at the monitoring sites where at least $4 \mathrm{yr}$ of data were available. The Theil-Sen method (Theil, 1950; Sen, 1968), available in the Openair software (Carslaw, 2012; Carslaw and Ropkins, 2012), was applied to the monthly averages to calculate the regression parameters of the trends including slope, uncertainty in the slope and the $p$ value. The applied method yields accurate confidence intervals even with non-normal data and it is less sensitive to outliers and missing values (Hollander and Wolfe, 1999).
Data were deseasonalized and all the regression parameters were estimated through bootstrap resampling. The slopes indicate how concentrations have changed through time and are expressed in units $\left(\mu \mathrm{g} \mathrm{m}^{-3}\right.$ in our case) per year. The $p$ values show whether the calculated trends are statistically significant. A statistically significant trend was assumed at the 90th percentile significance level $(p<0.1)$, meaning that there was a $90 \%$ chance that the slope was not due to random chance. The $p$ values $>0.1$ and $\leq 0.01$ indicate insignificant and highly significant trends, respectively.

\section{Results}

\section{1 nmC concentrations}

Figures 2 and 3 show the mean annual concentrations of $\mathrm{nmC}$ measured at the 78 sites ordered from the lowest to the highest concentration. Data did not evidence any spatial trends of carbonaceous aerosols across Spain. Conversely, an increase by a factor of 5 is evidenced from remote, rural to traffic and industrial sites. The following $\mathrm{nmC}$ concentration ranges may be deduced from these figures:

- Remote sites: $1.1-1.3 \mu \mathrm{g} \mathrm{m}^{-3}$.

- Rural sites: 1.8-2.6 $\mu \mathrm{g} \mathrm{m}^{-3}$ for most sites, with one site (Bemantes) reaching higher levels $\left(3.5 \mu \mathrm{g} \mathrm{m}^{-3}\right)$ probably due to higher emissions from regional domestic and agricultural biomass combustion and forest fires.

- Industrial sites: $3.3-7.0 \mu \mathrm{g} \mathrm{m}^{-3}$ for most sites, depending on the type of industry, but with mean concentrations exceeding $5 \mu \mathrm{g} \mathrm{m}^{-3}$ in petrochemical and coke estates or industrial-urban sites. In Bailén, concentrations reached anomalously high values $\left(10.6 \mu \mathrm{g} \mathrm{m}^{-3}\right)$ due to the large emissions from numerous old manufacturing installations of bricks and pottery. Conversely, one suburban industrial site (Plaza Castillo-Almeria) oriented to monitor the impact of power generation, and a harbour-influenced site (Santa Cruz) recorded relatively low concentrations $\left(1.8 \mu \mathrm{g} \mathrm{m}^{-3}\right)$.

- Urban and suburban background sites: 3.0-6.5 $\mu \mathrm{g} \mathrm{m}^{-3}$ for most sites.

- Traffic sites: $4.4-5.9 \mu \mathrm{g} \mathrm{m}^{-3}$ at five small $(<100000 \mathrm{in}$ habitants) or medium-sized (100000-560000 inhabitants) cities (Granada, Almería, Málaga, TorrelavegaBarreda and Bilbao), and 8.3-10.3 $\mu \mathrm{g} \mathrm{m}^{-3}$ in the larger or industrialized cities (Madrid, Barcelona, Sabadell, Cartagena and Girona).

\subsection{EC and OC concentrations}

Annual average concentrations of EC (Figs. 3 and 4) markedly increased by a factor of up to 50 from remote to 


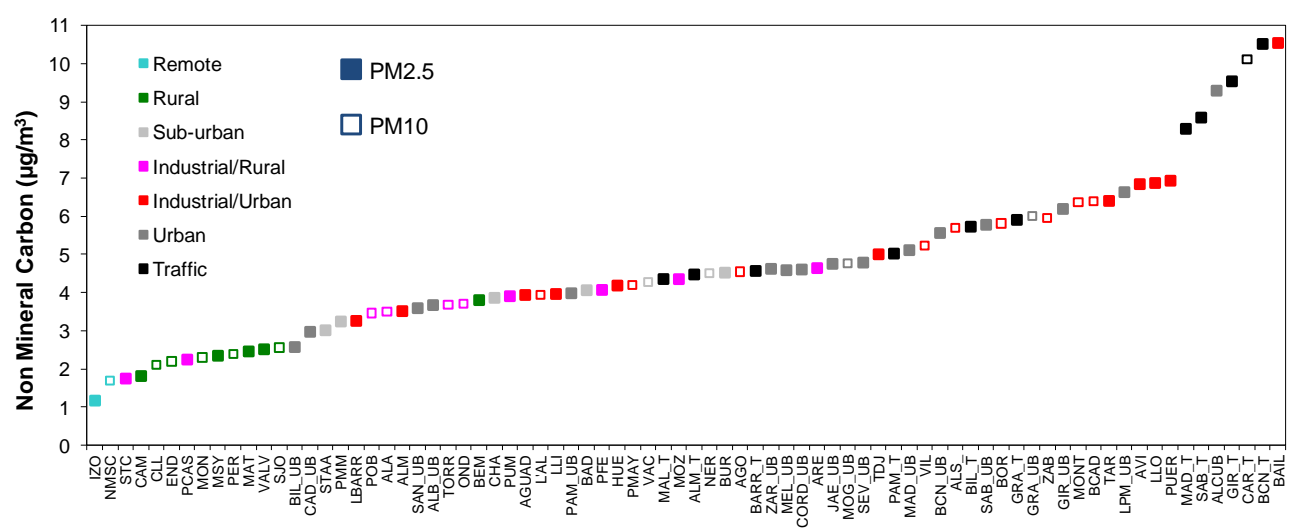

Fig. 2. Mean nmC concentrations in $\mathrm{PM}_{2.5}$ (solid) and $\mathrm{PM}_{10}$ (blank), recorded in 78 study sites ordered from low to high and classified according to the site type.
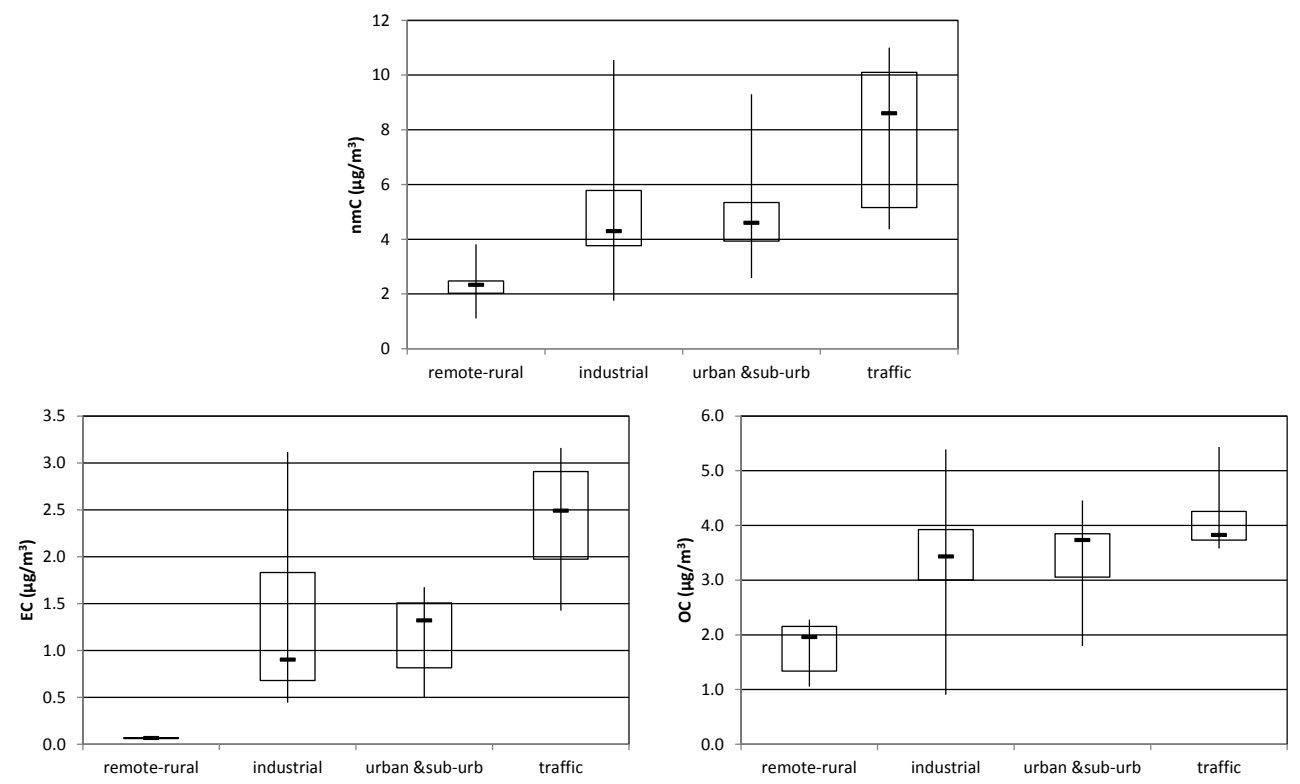

Fig. 3. Maximum, minimum, 25th percentile, mean and 75th percentile values for nmC, EC and OC concentrations measured in this study.

traffic and some industrial sites. According to the EC concentrations measured, the following ranges were evidenced:

- Remote sites: 0.07-0.13 $\mu \mathrm{g} \mathrm{m}^{-3}$.

- Rural sites: $0.2-0.3 \mu \mathrm{g} \mathrm{m}^{-3}$.

- Industrial-rural sites: $0.5-0.9 \mu \mathrm{g} \mathrm{m}^{-3}$.

- Industrial-urban sites: $0.8-1.0 \mu \mathrm{g} \mathrm{m}^{-3}$ in most cases, $1.7-2.3 \mu \mathrm{g} \mathrm{m}^{-3}$ in coke and metallurgical estates, and $3.1 \mu \mathrm{g} \mathrm{m}^{-3}$ in the above-mentioned brick production estate with a large number of very old installations (Bailén).
- Urban background sites: $0.6-0.9 \mu \mathrm{g} \mathrm{m}^{-3}$ in small and mid-sized cities, and $1.3-1.7 \mu \mathrm{g} \mathrm{m}^{-3}$ in the larger cities. Medium and small cities, such as Granada (250000 inhabitants) and Melilla (80000 inhabitants), also fall in the $1.3-1.7 \mu \mathrm{g} \mathrm{m}^{-3}$ range due to the location of the station (Granada) and to large influence from shipping emissions and also transboundary EC pollution from the nearby Moroccan border (Melilla).

- Traffic sites: $1.4 \mu \mathrm{g} \mathrm{m}^{-3}$ in medium-sized cities (Barreda-Torrelavega), and 3.2-4.1 $\mathrm{g} \mathrm{m}^{-3}$ in the larger or industrialized cities (Madrid, Sabadell).

For OC concentrations (Figs. 3 and 4) the range of variation is much narrower when compared with EC. The increase from remote to traffic sites reached only a factor of 5, six times lower than that obtained for EC. According to 


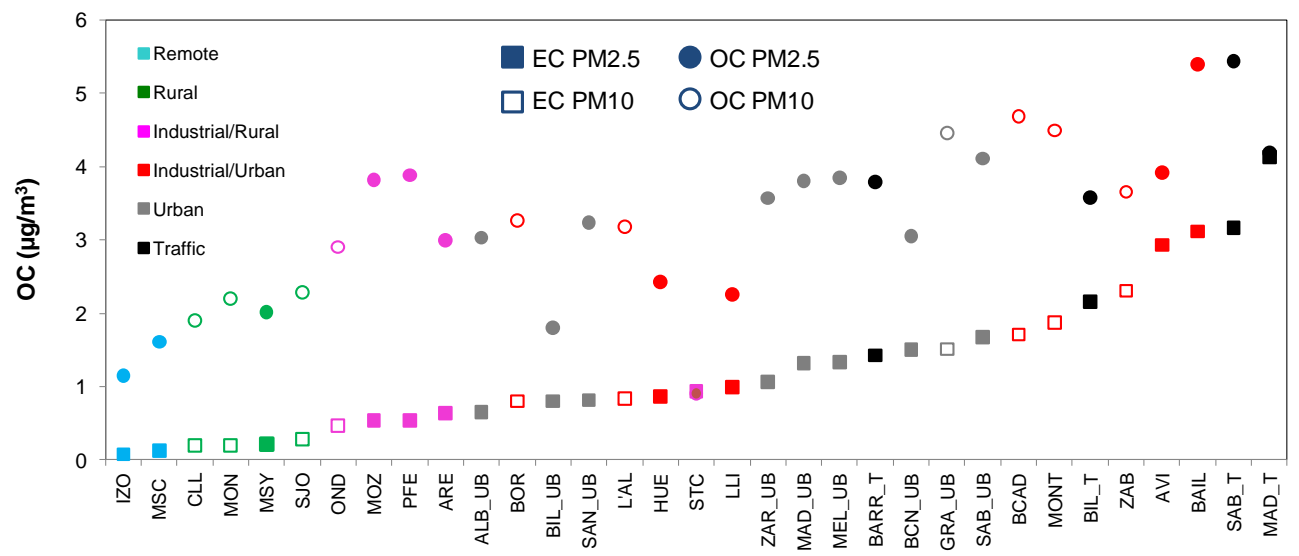

Fig. 4. Mean EC and OC levels in $\mathrm{PM}_{2.5}$ (solid) and $\mathrm{PM}_{10}$ (blank) recorded in the 33 study sites ordered from low to high EC levels and classified according to the site type.

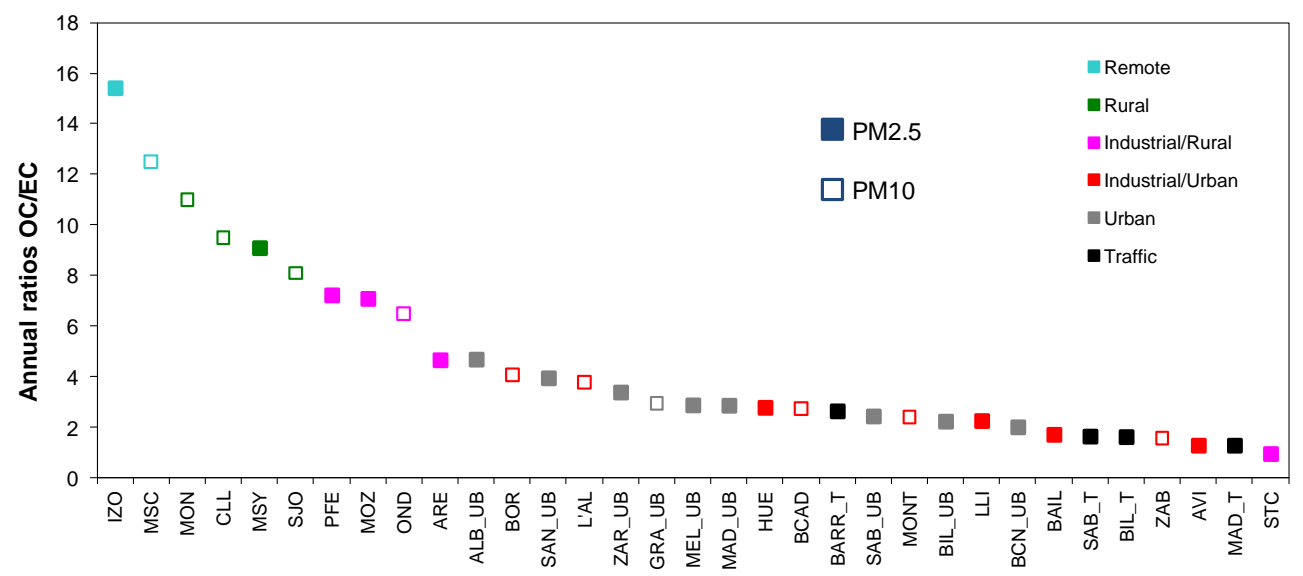

Fig. 5. Mean annual OC /EC ratios in $\mathrm{PM}_{2.5}$ (solid) and $\mathrm{PM}_{10}$ (blank) recorded in the 33 study sites ordered from high to low and classified according to the site type.

the $\mathrm{OC}$ concentrations measured, the following ranges were evidenced:

- Remote sites: $1.1-1.6 \mu \mathrm{g} \mathrm{m}^{-3}$.

- Rural sites: 2.0-2.3 $\mu \mathrm{g} \mathrm{m}^{-3}$.

- Industrial sites, including industrial-rural sites: 2.3$4.7 \mu \mathrm{g} \mathrm{m}^{-3}$ in most cases, and $5.4 \mu \mathrm{g} \mathrm{m}^{-3}$ in the brick production estate of Bailén.

- Urban background sites: $1.8-4.5 \mu \mathrm{g} \mathrm{m}^{-3}$.

- Traffic sites: $3.6-5.4 \mu \mathrm{g} \mathrm{m}^{-3}$.

Sampling artifacts for OC were not avoided with the methodology used, as previously stated (Viana et al., 2007), with a rough estimation of around $10-15 \%$ of the total OC (positive artifact) for low-volume sampling being assumed (this being much higher than for high-volume samplers as described by Turpin et al., 2000). Thus, for a hypothetical extreme scenario in which a positive OC artifact of $15 \%$ was assumed at traffic sites, and a negative artifact of $0 \%$ was assumed at remote sites (Chow et al., 2010b), the above-mentioned traffic/remote factor for $\mathrm{OC}$ would decrease to 4 . As a result, the difference regarding the traffic/remote factors for OC (4) and EC (up to 50) would be even larger if sampling artifacts were taken into account.

As expected, OC/EC annual ratios (Fig. 5) markedly decreased by a factor of 10 from the remote to traffic and some industrial sites. According to the ratios measured, the following ranges were evidenced:

- Remote sites: 12-15.

- Rural sites: 8-11.

- Industrial-rural sites 5-8.

- Most industrial sites: 2.3-4.1. Lower ratios (1.6-1.9) were found at coke and metallurgy hotspots, and 0.8 in the harbor site influenced by road traffic and an old petrochemical plant (Santa Cruz). 

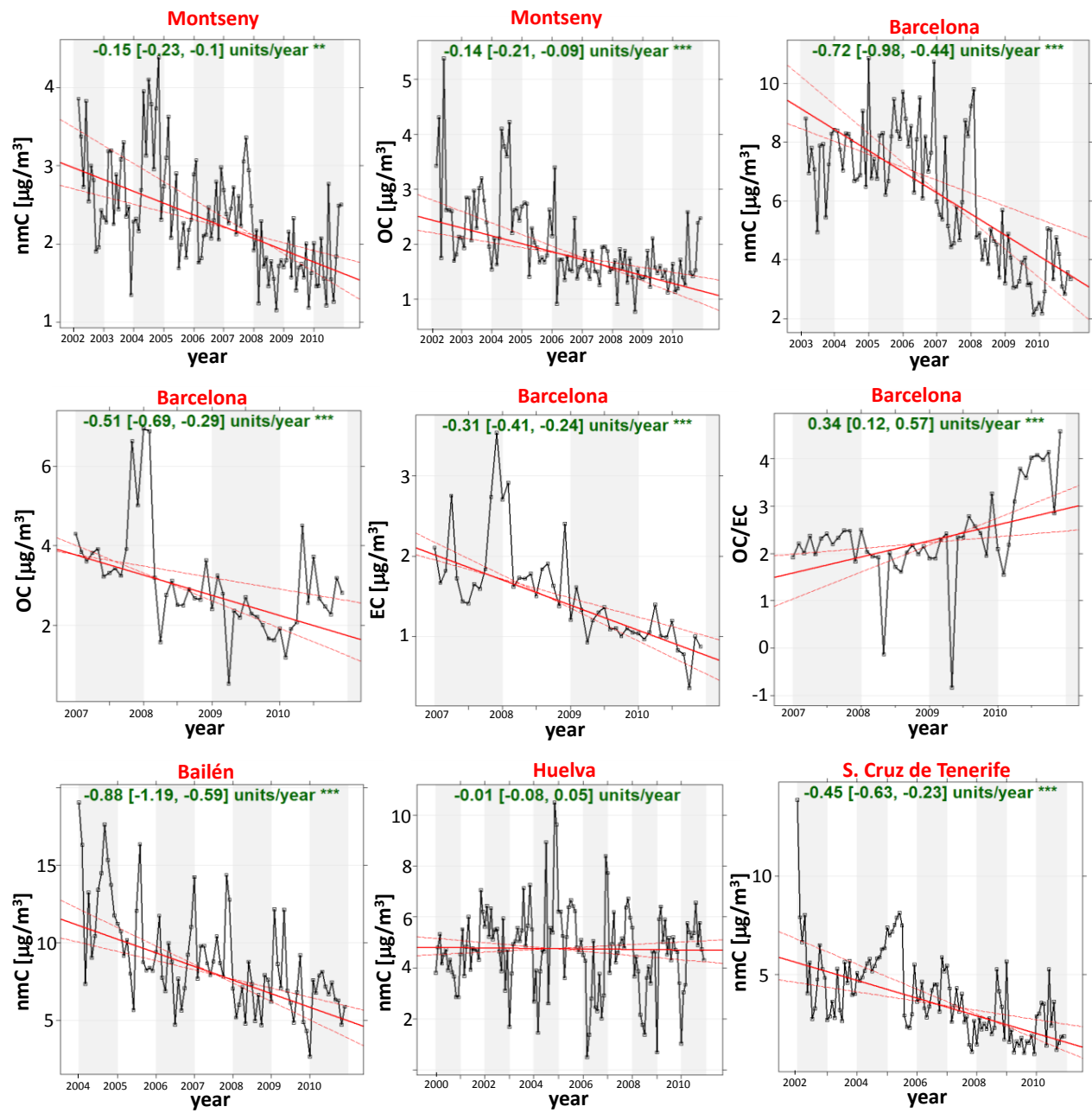

Fig. 6. Temporal trends for $\mathrm{nmC}$ in $\mathrm{PM}_{2.5}$ at Montseny, Barcelona, Bailén, Huelva and Santa Cruz de Tenerife. Plots show the deseasonalized monthly mean concentrations. The solid red line shows the trend estimate and the dashed red lines show the $95 \%$ confidence intervals for the trend. The overall trend and the $95 \%$ confidence intervals in the slope (between brackets) are shown at the top as units $\left(\mu \mathrm{g} \mathrm{m}^{-3}\right)$ per year. The ${ }^{* *}$ and ${ }^{* * *}$ indicate that the trend are significant to the 0.01 and 0.001 levels, respectively. The OC concentrations for Montseny (2002-2010) and the OC and EC concentrations and OC/EC for Barcelona (2007-2010) are also presented.

- Urban background sites: 4.0-5.6 in the medium-small cities (Albacete, Zaragoza and Santander) and 2.0-3.2 in the larger and/or more industrialized/high-trafficvolume sites such as Madrid, Barcelona, Sabadell, Granada and Melilla. In Melilla the low OC/EC ratio may be due to the high influence of shipping emissions, increasing the EC concentrations, in this site close to the Gibraltar Strait (and to transboundary pollution across the Moroccan border).

- Traffic sites: 1.6-1.7 in large cities, around 2.5 in small cities.

\subsection{Inter-annual trends}

Decreasing trends for carbonaceous compounds were observed at almost all stations through time, with significance levels $p$ ranging from 0.001 to 0.1 in many cases, and with more significant and robust results obtained for stations with more than $5 \mathrm{yr}$ of measurements. This is now discussed in more detail for each type of site. Figure 6 shows some examples of the temporal trends for selected stations as representative of regional (Montseny), urban (Barcelona), industrial (Bailén), urban-industrial (Huelva) and suburban-industrial (Santa Cruz de Tenerife) environments.

Remote background (Montsec): the concentrations of nmC did not exhibit clear trends (2006-2011), likely due to the position of this monitoring station ( $1570 \mathrm{~m}$ a.s.l.), often above the planetary boundary layer, making anthropogenic-driven 
trends more diluted when compared with other stations in Spain.

Regional background (Montseny): significant decreases were observed for nmC ( $p=0.01)$ and OC $(\mathrm{p}=0.001)$ concentrations in $\mathrm{PM}_{2.5}$ during the period 2002-2010. Both $\mathrm{nmC}$ and $\mathrm{OC}$ concentrations decreased at a rate of around $-0.2 \mu \mathrm{g} \mathrm{m}^{-3} \mathrm{yr}^{-1}$ (Fig. 6), which is equivalent to a decrease of $1.4 \mu \mathrm{g} \mathrm{m}^{-3}$ and $1.3 \mu \mathrm{g} \mathrm{m}^{-3}$ for $\mathrm{nmC}$ and $\mathrm{OC}$, respectively, between 2002 and 2010. No significant trend was observed for EC concentrations (data not shown). However, the annual mean EC concentrations at Montseny were very low - ranging between $0.2 \mu \mathrm{g} \mathrm{m}^{-3}$ and $0.3 \mu \mathrm{g} \mathrm{m}^{-3}$ in the 2002-2010 period - and highly influenced by the TOT split point that depends on the measurement protocol used.

Urban background (Barcelona): over the period 20032010 a significant decreasing trend was observed for $\mathrm{nmC}$ in $\mathrm{PM}_{2.5}$ at a rate of $-0.7 \mu \mathrm{g} \mathrm{m}^{-3} \mathrm{yr}^{-1}$ (around $50 \%$ decrease at $p=0.001$ ) (Fig. 6). In absolute terms, this decrease was equivalent to $3.6 \mu \mathrm{g} \mathrm{m}^{-3}$ from 2003 to 2010. Significant decreases of nmC concentrations (31-35\%) were also detected at other urban background sites (Granada, Córdoba, Cádiz, Jaén, Sevilla, Málaga). Similarly, statistically significant $(p<0.01)$ trends were detected for OC and EC between 2007 and 2010. The OC/EC ratio in Barcelona over the period 2007-2010 increased (at $p=0.001$ ) at the rate of $0.3 \mathrm{yr}^{-1}$, indicating a higher relative decreasing rate of EC when compared with OC in Barcelona.

Traffic sites (Madrid): $\mathrm{nmC}$ concentrations in $\mathrm{PM}_{2.5}$ were only available for the years 2000, 2007 and 2011; thus data were not sufficient for the application of the TheilSen method. A simple linear regression applied to the data showed a decreasing trend for $\mathrm{nmC}$ concentrations at a rate of $-0.7 \mu \mathrm{g} \mathrm{m}^{-3} \mathrm{yr}^{-1}$, which is similar to the decreasing rate observed for $\mathrm{nmC}$ in Barcelona, with a regression coefficient $R^{2}$ of 0.99 .

Urban/industrial sites: with the exception of Huelva, at most sites clear decreasing trends were evidenced fornmC for both $\mathrm{PM}_{10}$ and $\mathrm{PM}_{2.5}$. For the period 2007-2010, decreasing trends were obtained ranging from $-0.2 \mu \mathrm{g} \mathrm{m}^{-3} \mathrm{yr}^{-1}$ to $-0.6 \mu \mathrm{g} \mathrm{m}^{-3} \mathrm{yr}^{-1},(18-27 \%$ decreases, $1.8-2.5 \mu \mathrm{g} \mathrm{m}^{-3}$ in total). For these stations the observed decreasing trends were less significant $(0.01<p \leq 0.1)$ compared to urban sites. The strongest decrease in $\mathrm{nmC}$ concentrations was registered in Bailén over the period 2004-2010 at a rate of $-0.9 \mu \mathrm{g} \mathrm{m}^{-3} \mathrm{yr}^{-1}$ (around $50 \%$ or $6.90 \mu \mathrm{g} \mathrm{m}^{-3}$ ) (Fig. 6), due to the reduction in brick manufacture activities caused by the financial crisis.

The only site where nmC concentrations did not decrease but instead remained almost constant between 2000 and 2010 was Huelva (urban industrial, SW IP, Fig. 6). Conversely, nmC levels showed increasing trends only at two sites (Matalascañas, regional background, SW IP; and Plaza Castillo-Almería, power generation, regional background, SE IP), with increases ranging between 0.1 and $0.4 \mu \mathrm{g} \mathrm{m}^{-3} \mathrm{yr}^{-1}$.

\section{Discussion}

\subsection{Ambient concentrations of carbonaceous aerosols}

The spatial variability of nmC across different atmospheric environments in this study shows that anthropogenic carbonaceous aerosols in Spain within the period 1999-2010 mainly originated from road traffic, and in a minor proportion from biomass burning (domestic and agricultural biomass burning and wild fires) and industrial and shipping emissions. Urban air pollution is markedly dominated by emissions from vehicular traffic, with the major Spanish cities (especially Barcelona) suffering from the highest vehicle density, with a high proportion of diesel cars, in Europe. Biomass burning contributions may have an impact in rural areas but have little impact on air quality in urban areas. In Barcelona, three studies (Minguillón et al., 2011; Reche et al., 2012; Viana et al., 2013b) quantified these contributions as $3 \%$ of $\mathrm{PM}_{10}$ and $\mathrm{PM}_{2.5}$ (annual mean), while this percentage increased up to $5 \%$ of $\mathrm{PM}_{1}$. Annually, biomass burning emissions accounted for $19-21 \%$ of total OC levels in $\mathrm{PM}_{10}$, $\mathrm{PM}_{2.5}$ and $\mathrm{PM}_{1}$. Absolute contributions of biomass burning were higher in winter at urban and regional sites. Naturally emitted carbonaceous aerosols (both primary and secondary) may also be considered significant in the regional background, particularly in spring and summer (Seco et al., 2011; Minguillón et al., 2011), and especially in the central and northern regions of the Iberian Peninsula.

Reviewing the carbonaceous aerosol concentrations in $\mathrm{PM}_{2.5}$ across Spain, mean annual concentrations of nmC range from around $1 \mu \mathrm{g} \mathrm{m}^{-3}$ at the most remote and pristine sites to around $10 \mu \mathrm{g} \mathrm{m}^{-3}$ in the most polluted cities. Petrochemical and coke estates provide notable industrial point sources of nmC, and biomass burning (domestic, agricultural and forest fires) is probably causing an increase of around $1 \mu \mathrm{g} \mathrm{m}^{-3}$ in the annual $\mathrm{nmC}$ mean at regional background sites in northern Spain with respect to the rest of the Spanish territory. This is deduced from the difference on nmC concentrations from most regional background sites in this study $\left(1.8-2.6 \mu \mathrm{g} \mathrm{m}^{-3}\right)$ and the concentration recorded at the regional site of Bemantes $\left(3.5 \mu \mathrm{g} \mathrm{m}^{-3}\right)$, highly influenced by biomass burning emissions in the region.

$\mathrm{OC}$ and $\mathrm{EC}$ data similarly show marked differences from remote to traffic sites $\left(1.1-1.6 \mu \mathrm{g} \mathrm{m}^{-3}\right.$ of $\mathrm{OC}$; $\mathrm{OC} / \mathrm{EC}=12-$ 15 compared with $3.8-5.4 \mu \mathrm{g} \mathrm{m}^{-3}$ of $\mathrm{OC}$; OC $/ \mathrm{EC}=1.6-1.7$, respectively). This reflects the impact of emissions from traffic and specific industrial processes. However, the OC concentration range is much narrower than for $\mathrm{EC}$ as the increase in OC concentrations from remote to traffic sites reached only a factor of 5 (as opposed to 50 for EC). 

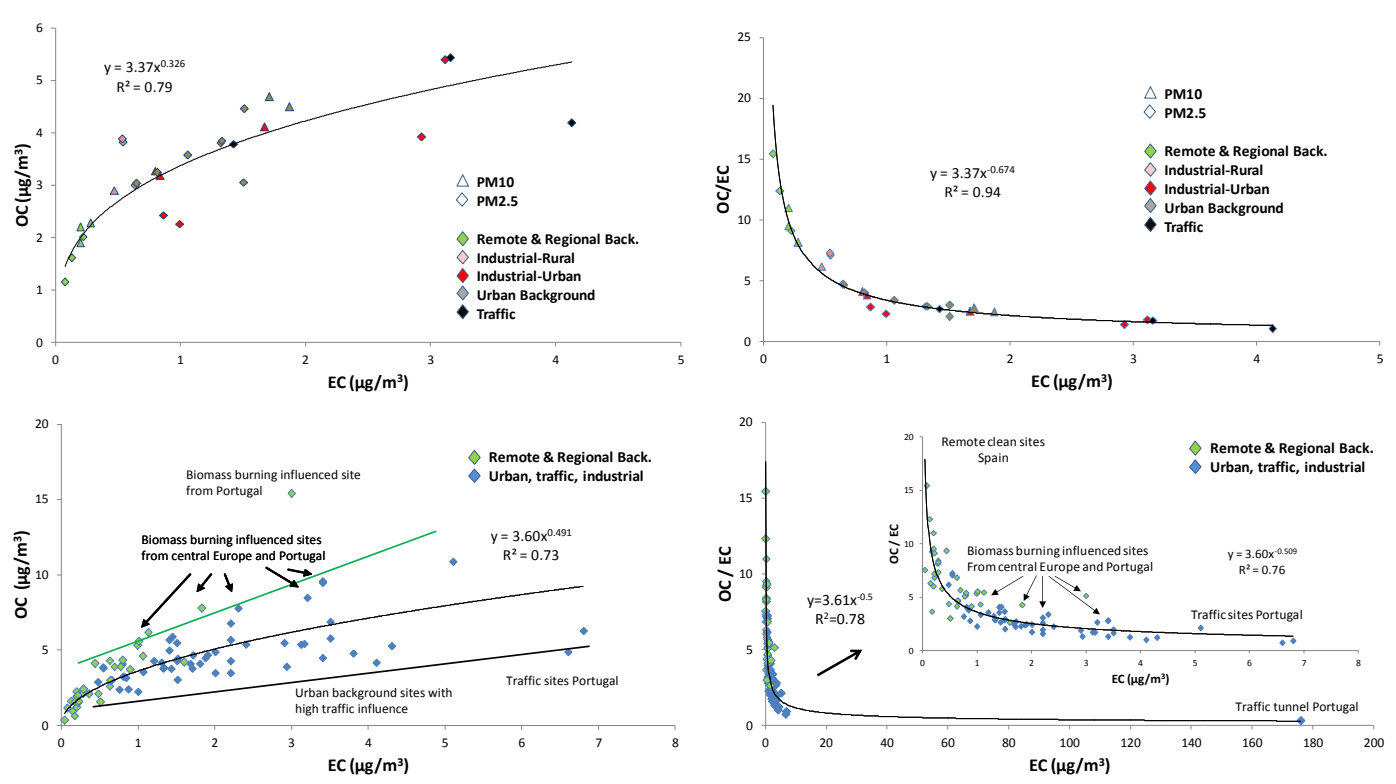

Fig. 7. Correlation and regression equations between mean OC and EC levels (two left) and the ratios OC/EC with EC levels (two right) obtained in this study for Spanish only (two top) and Spanish and other European (bottom) sites (Yttri et al., 2007; Pio et al., 2007, 2011; Grivas et al., 2012, and references therein).

Plotting OC/EC average ratio against EC concentrations (Fig. 7) shows similar results to those obtained by Pio et al. (2007, 2011), but in that study the higher influence of biomass burning emissions provoked a higher OC/EC ratio. As shown in Fig. 7, correlation between yearly averaged $\mathrm{OC}$ and EC concentrations adjusts relatively well to a potential equation $\left(\mathrm{OC}=3.37 \mathrm{EC}^{0.326}, R^{2}=0.8, n=33\right)$. A similar equation is obtained when including average concentrations obtained at other European sites $\left(\mathrm{OC}=3.60 \mathrm{EC}^{0.491}\right.$, $R^{2}=0.7, n=83$ ) reported by Pio et al. $(2007,2011)$, Yttri et al. (2007), Spindler et al. (2010), Grivas et al. (2012) and references therein. Stations on the right-hand side of the fitting curve correspond to traffic sites. The left-hand side of the curve contains values from remote sites. Values above the curve usually have a high influence from biomass burning, whereas most values on the curve or below correspond to traffic-influenced urban and industrial sites. These data may be very useful for the modelling community.

Recent data on ${ }^{14} \mathrm{C}$ at Barcelona (Minguillón et al., 2011) showed a high proportion of non-fossil OC (52-60\%) in the urban background. This probably indicates that a large proportion of urban SOA can be formed inside the city from regional VOCs (with a high proportion of biogenic VOCs) due to the oxidative environment created by urban pollution. Minguillón et al. 2011 has evidenced that absolute concentrations of fossil OC were also higher in winter than in summer at Barcelona due to stronger accumulation of pollutants during the cold season with lower atmospheric dispersion, and probably to higher fossil combustion for residential heating. Concentrations of non-fossil OC and non-fossil EC at Barcelona were twice as high in winter than in summer, prob- ably due to a higher contribution of biomass burning and reduced mixing in winter. At MSY, non-fossil OC was similar in summer and winter, despite the lower biomass burning contribution in summer as evidenced by the lower non-fossil EC. These authors estimated biomass burning OC to account for $30-35 \%$ of the non-fossil OC at both sites and seasons (17-21\% of total OC), with the exception of MSY in summer, where it only accounted for $12 \%$ of total OC. This can likely be explained by a higher contribution of biogenic SOA in summer due to higher biogenic emissions and enhanced photochemistry. Other contributions to modern OC, such as the contribution of cooking organic aerosols (COA) identified in Barcelona by Mohr et al. (2012), cannot be discarded for urban areas. However, their mass contribution is still unclear. Mohr et al. (2012) estimated COA contributing to $17 \%$ of OA in Barcelona's urban background, but it is clear that at remote and regional background sites this contribution will be much lower, probably negligible.

The slope of the regression equation between OC/EC and EC (Fig. 7) is very high (8) for the remote and rural sites and progressively lower as EC increases towards the industrial (1.2) and urban and traffic sites (0.8).

Typically the ratio OC/EC is lower than 0.5 for diesel emissions (Zielinska et al., 2004; El Haddad et al, 2009). Pio et al. (2011) found minimum OC/EC ratios (attributed to primary traffic contributions) at urban background sites in Europe to be around 0.7 in $\mathrm{PM}_{2.5}$ and 1.0 in $\mathrm{PM}_{10}$. If we consider an OC/EC ratio for traffic sites close to 1.6-1.7, and we have taken into account that $55 \%$ of the Spanish fleet are diesel cars, it is clear that even at traffic sites the contribution of SOA (from petrol, biogenic or other sources) to 


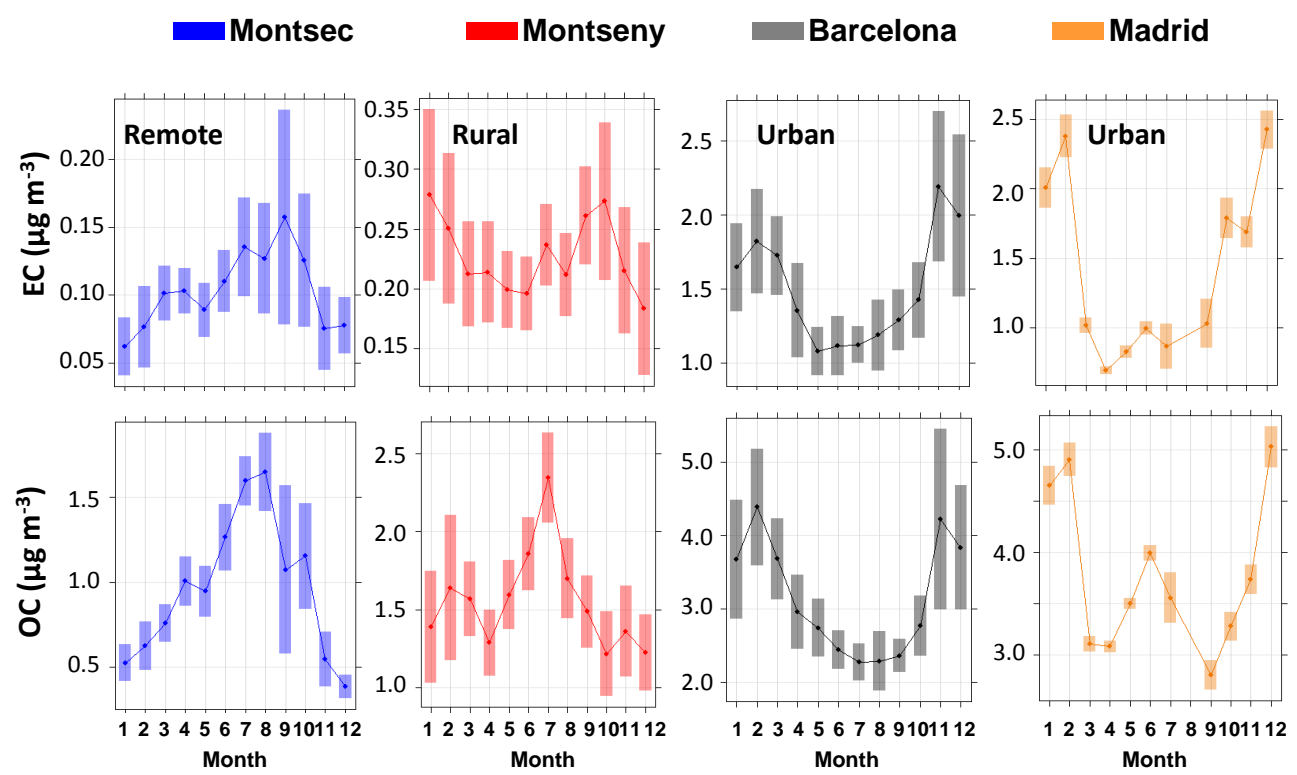

Fig. 8. Monthly mean OC and EC concentrations in $\mathrm{PM}_{2.5}$ at Montsec (remote), Montseny (rural), Barcelona and Madrid (urban background and traffic sites). Bars represent $95 \%$ confidence intervals.

OC is very relevant. The above primary OC/EC ratios are closer to those determined at the Atlantic island site of Santa Cruz de Tenerife (0.8), where probably both biogenic and anthropogenic SOA formation have a lower contribution on $\mathrm{OC}$ levels. According to our results the $\mathrm{OC} / \mathrm{EC}$ ratios of the regression equations is 7-10 times higher in the remote and regional background sites than in the urban and industrial areas.

Thus, the high correlation observed between OC and EC across Europe - especially for rural background sites regardless of vegetation type, climate and photochemistry - is surprising. Although correlation is also good for urban, traffic and industrial sites, the correlation between OC and EC concentrations is not as marked as for the rural sites, probably due to the different impact of biomass burning and traffic/industrial sources. The OC/EC ratio usually depends on the type of fuel, being higher for biomass and lower for fossil fuel (Novakov et al., 2000; Szidat et al., 2007). Primary petrol exhaust emissions have also high OC/EC ratios, but the emission levels in absolute values are small compared to the diesel primary exhaust emissions, at least for EURO3 and older diesel cars.

\subsection{Inter-annual trends}

One especially interesting finding was the decreasing annual trends observed at almost all the stations and station types. The decreasing trend of $\mathrm{OC}+\mathrm{EC}$ (or $\mathrm{nmC}$ ) of -0.4 to $-0.7 \mu \mathrm{g} \mathrm{m}^{-3} \mathrm{yr}^{-1}$ measured at the largest cities in Spain may be a consequence of the implementation of environmental action plans or legislation, such as EURO4 and EURO5 standards to reduce diesel PM emissions, and the European
Directive 1996/61/CE (IPPC Directive: Integrated Pollution Prevention and Control) on the reduction of industrial emissions. The Spanish vehicle fleet has undergone an intense dieselization since the 1990s. This resulted in a proportion of diesel vehicles reaching $10 \%$ in 1991 that markedly increased to $55 \%$ in 2010, with annual sales of diesel vehicles reaching $70 \%$. This increase has probably caused a marked increase of EC and OC emissions from road transport. However, the effort done by car manufacturers to meet EURO4 (since 2005) and EURO5 (since 2009) PM emission standards may have had an important impact in reducing ambient mass concentrations of carbonaceous aerosols in urban areas.

Slightly higher decreasing trends may be due to local effects, such as those found in Madrid, probably due to the change in the traffic regime in the proximity of this site due to the construction of a tunnel. In the last years, the financial crisis may have also influenced these trends. However, the decreasing trend was already evident before 2008, when the crisis started, and it was even more marked before this year for OC at some sites, such as Barcelona and Montseny (Fig. 6). Although in some cases we may find a lower decreasing trend for OC levels since $2008, \mathrm{nmC}$ trends tend to evidence minimum values around 2010 coinciding with the low PM levels recorded in the western Mediterranean with the most negative North Atlantic Oscillation index in the last century (Cusack et al., 2012). Increasing or constant nmC concentrations were only found in very specific areas with industrial influence. This overall improvement in air quality is especially well demonstrated at stations with more than $5 \mathrm{yr}$ of measurements, and emphasizes the value of obtaining continuous, long-term monitoring databases. 


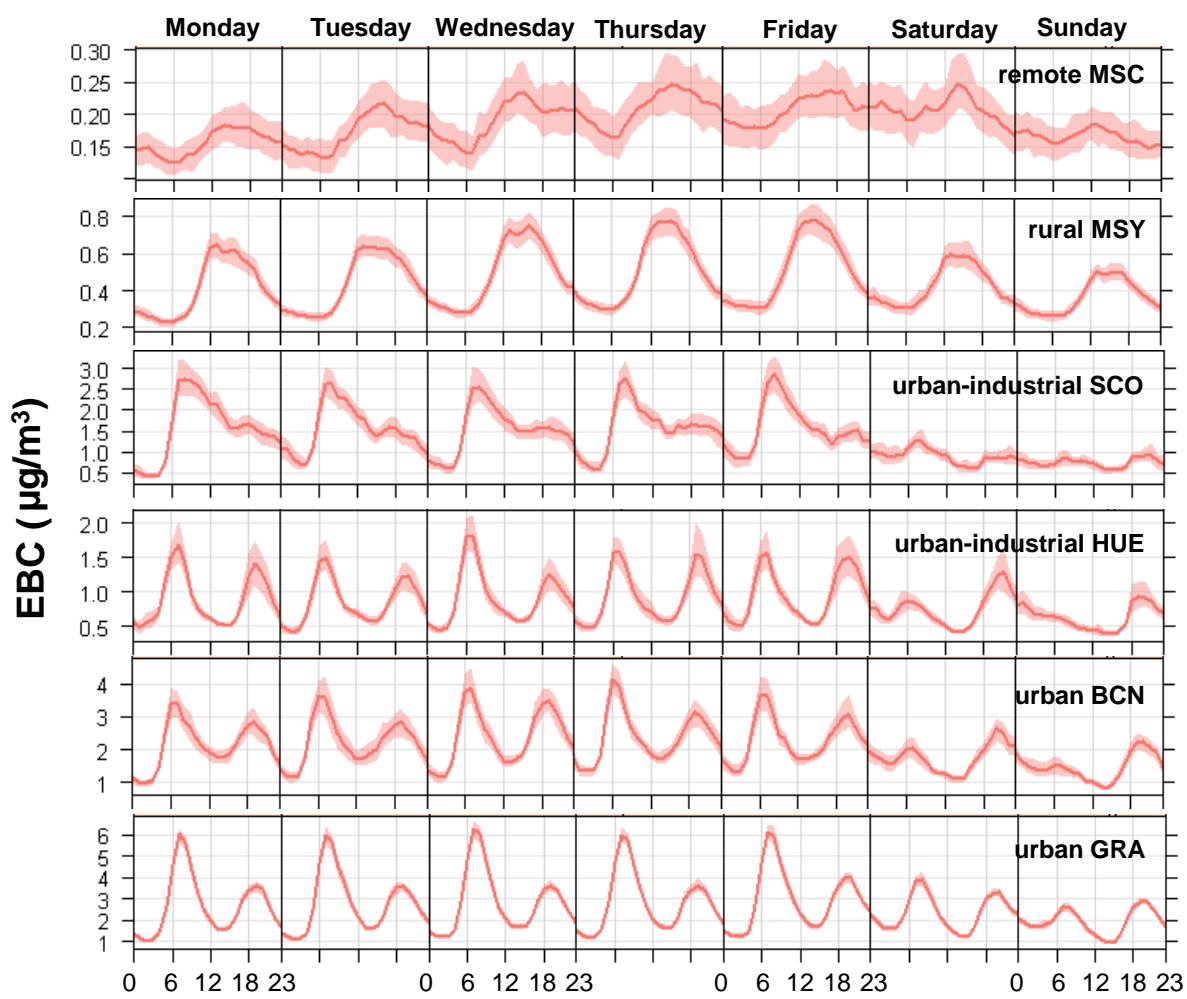

Fig. 9. Mean diurnal patterns of EBC for the different week and weekend days at different environments in Spain. Shaded areas represent $95 \%$ confidence interval in the mean.

\subsection{Seasonal trends}

Distinct seasonal variability was found regarding OC and EC concentrations at traffic, urban, regional and remote background sites. With the following examples we describe seasonal patterns at the following selected sites: (a) one traffic site (Madrid); (b) one urban background site (Barcelona), (c) one regional (Montseny) and (d) one remote site (Montsec) (Fig. 8).

OC concentrations were higher during winter at the traffic and urban sites, decreasing during the warmer months. The higher OC concentrations measured during winter may be related to atmospheric conditions as important anticyclonic episodes are usually recorded over the Iberian Peninsula during winter, producing the accumulation of pollutants in the vicinity of their emission sources (mainly vehicular emissions at traffic and urban sites). In addition, the lower temperatures prevent semi-volatile organic compounds from volatilizing.

Conversely, OC concentrations at the remote and rural sites increased during the warmer months. This is mainly related to the increase of biogenic emissions during summer (Seco et al., 2011) but also to the summer atmospheric conditions favouring higher photochemistry (higher $\mathrm{O}_{3}, \mathrm{UV}$ and $T$ coincident with enhanced biogenic emissions of VOCs) and recirculation of air masses over the area (Pérez et al., 2008).
For EC the seasonal variability is similar to OC for the traffic and urban sites, with higher concentrations recorded during the winter. This similar pattern for $\mathrm{OC}$ and $\mathrm{EC}$ is consistent with the $\mathrm{OC} / \mathrm{EC}$ ratios found for urban and traffic sites, similar to those of primary traffic emissions. Hence, it is possible to conclude that the variation of $\mathrm{OC}$ and EC concentrations is mainly driven by dispersion conditions. At the regional site (Montseny), EC concentrations are characterized by higher concentrations in winter and autumn. Such higher concentrations during winter are attributed to the influence of winter regional pollution episodes (Pey et al., 2010), whereas the September-October higher concentrations are related with other causes (agricultural biomass burning or other regional sources). At the remote site (Montsec), a clear increase in EC concentrations was only recorded in September, probably associated with agricultural biomass burning. No clear maxima were observed in winter, given that the monitoring site lies most of the time above the mixing boundary layer.

\subsection{Daily and weekly evolution}

Clear differences can be observed in the hourly evolution of EBC in different types of environments (Fig. 9). At urban sites (Barcelona and Granada), EBC concentrations trace road traffic contributions accurately. Two distinct maxima are typically observed in working days at morning and evening 
rush hours (07:00 and 19:00 UTC). This daily pattern varies proportionally to those of primary gaseous emissions from road traffic such as $\mathrm{CO}$ and $\mathrm{NO}_{\mathrm{x}}$ (data not shown). The $\mathrm{EBC} / \mathrm{CO}$ and $\mathrm{EBC} / \mathrm{NO}_{\mathrm{x}}$ ratios, however, are not constant among different sites due to different emission and dispersion patterns (Reche et al., 2011). A significant drop of EBC concentrations on weekends due to the reduced emissions from human activity is shown at urban and rural sites. Interestingly, the lowering in EBC concentrations, although smoother and with one day of delay, is also observed at the remote site.

At rural and remote sites, EBC peaks only once (in the afternoon) with this maximum corresponding to the arrival of pollution from the emission area, by means of mountain breezes. The distance from the emission sources seems to drive the variance of EBC concentrations, and thus the relative variation of the hourly mean values is higher at remote and rural sites (Fig. 9), being progressively reduced as the distance to the source decreases (at the urban and urbanindustrial sites). This is due to the cleansing effect of renewed air masses reaching rural sites that permit a large variability of EBC concentrations.

\section{Conclusions}

We interpreted variability of levels of carbonaceous aerosols based on large database from 78 monitoring stations across Spain. As expected, data show marked differences in average concentrations from the cleanest, most remote sites to the highly polluted major cities. Thurs, urban (and very specific industrial) pollution was found to markedly increase levels of carbonaceous aerosols in Spain, with a much lower impact of biomass burning.

Correlations between yearly averaged OC and EC concentrations adjust relatively well to a potential equation $\left(\mathrm{OC}=3.37 \mathrm{EC}^{0.326}, R^{2}=0.8, n=33\right)$. A similar equation is obtained when including average concentrations obtained at other European sites $\left(\mathrm{OC}=3.60 \mathrm{EC}^{0.491}, R^{2}=0.7, n=83\right)$. Stations on the right-hand side of the fitting curve correspond to traffic sites. The left-hand side of the curve is occupied by values from remote sites. Values above the curve usually have a high influence from biomass burning, whereas most values on or below the curve correspond to traffic influenced urban and industrial sites. These data may be very useful for the modelling community.

A clear seasonal variability in OC and EC concentrations was detected, with higher concentrations during winter at the traffic and urban sites, contrasting with $\mathrm{OC}$ at rural sites (increasing during the warmer months). Urban sites across Spain show classical patterns of hourly variations in EBC concentrations which accurately depict daily traffic flows, whereas a single midday pollution peak, commonly driven by outflows from nearby urban centres, characterizes remote and rural sites.

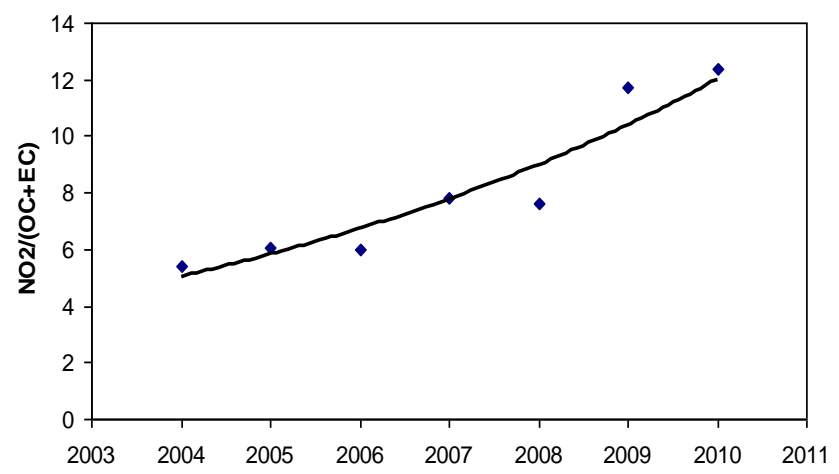

Fig. 10. $\mathrm{NO}_{2} /(\mathrm{OC}+\mathrm{EC})$ rates as obtained from $\mathrm{OC}+\mathrm{EC}$ measurements in $\mathrm{PM}_{2.5}$ performed at the Barcelona urban background site and from $\mathrm{NO}_{2}$ measured at another urban background site in Barcelona (Ciutadella) by the Air Quality Department of the Autonomous Region of Catalonia.

One especially interesting finding was the decreasing annual trends observed at almost all the stations and station types. This may be the consequence of the implementation of environmental action plans or legislation, such as EURO4 and EURO5 standards to reduce diesel PM emissions. In the last years, the financial crisis may have also influenced these trends, although these were already present before 2008, when the crisis started. Increasing or constant $\mathrm{nmC}$ concentrations were only found in very specific industrial influenced areas. In contrast with $\mathrm{nmC}$, ambient air $\mathrm{NO}_{2}$ trends in most EU large cities have not been seen to decrease as described here for $\mathrm{nmC}$ (Williams and Carslaw, 2011). This is highly relevant for air quality regulations since $\mathrm{NO}_{2}$ has been considered a proxy of traffic-related PM. As shown in Fig. 10, in Barcelona the time trends of $\mathrm{NO}_{2} /(\mathrm{OC}+\mathrm{EC})$ have increased from around a value of 5 (2004) to the current value of $12(2010)$.

\subsection{Implications for atmospheric sciences and air quality policy}

WHO (2012) reported substantial health effects for BC and/or for substances that can condensate on the graphitized carbon that are indirectly measured by $\mathrm{BC}$ measurements. Furthermore, EBC variation reflects the impact of traffic emissions at urban sites, and can be considered as a good indicator of anthropogenic emissions at these sites. At regional and remote sites, variations of EBC may be attributed to other sources and processes, but average concentrations of EBC are considerably lower, with minimum implications for air quality and health (even if with potential effects on climate). EBC showed a significant and constant correlation with EC at urban sites across Spain showing that, although both parameters are not the same, they may be considered as equivalent and, consequently, suitable for tracing the impact of anthropogenic emissions. 
Currently no standardized methodology is available to determine EBC or EC, but WHO (2013) has already indicated the need to set up air quality guidelines for $\mathrm{BC}$. As mentioned before, the determination of OC and EC by thermal-optical methods implies uncertainties arising from several factors e.g. the selection of the split point, selected thermal protocol and the possible interference with carbonates (Cavalli et al., 2010; Karanasiou et al., 2011), among others. Measurement of EBC by absorption photometry needs to be corrected to ensure comparability (Müller et al., 2011), with correction algorithms being already available for some of these instruments.

It could be concluded that continuous monitoring of EBC by absorption photometers is an adequate strategy for air quality monitoring mainly at urban sites where this parameter can be considered as a good tracer of exposure to anthropogenic emissions. In a technical report for the European Environmental Agency (EEA), it was concluded that EBC monitoring would be viable in current European air quality networks where these types of instruments are already present (Viana et al., 2013a). As recently reported by WHO (2012), there is sufficient evidence of the association between cardiopulmonary morbidity and mortality with $\mathrm{BC}$ exposure. This review concluded that "a reduction in exposure to $\mathrm{PM}_{2.5}$ containing $\mathrm{BC}$ and other combustion-related particulate material for which $\mathrm{BC}$ is an indirect indicator should lead to a reduction in the health effects associated with PM and simultaneously contribute to the mitigation of climate change".

However, OC, including secondary OC, also has a potential health impact. Verma et al. (2009) have shown for Los Angeles in summer that both primary and secondary organic particles possess high redox activity. Photochemical transformations of primary emissions through atmospheric aging enhance the toxicological effect of primary particles in terms of generating oxidative stress and leading to subsequent damage in cells. Our results show that at rural sites there is a clear correlation between OC and EC concentrations. However, at urban sites the OC/EC ratio may vary considerably depending on the sources. Moreover, a rapid formation of secondary organic compounds was evidenced at the urban scale due to the oxidation of regional or local volatile organic compounds in the highly reactive urban environment. Consequently, the measurement of $\mathrm{nmC}(\mathrm{OC}+\mathrm{EC})$ should be a good indicator for air quality monitoring, providing more valuable information than simply monitoring EBC, especially when a reduction of EBC levels is expected due to the effect of EURO4, 5 and 6 standard emissions.

From the scientific and technical point of views this study reinforces the need for establishing reference methods for OC, EC, TC and EBC measurements in order to better compare PM speciation data and increase the potential use of these components for air quality monitoring because these are tracers of combustion emissions, in many cases causing exceedances of the $\mathrm{NO}_{2}$ and PM EU limit values.
There is a scientific need of developing intensive research on the origin of OC components, including both SOA (from both anthropogenic and natural origin) and POA (specially sources of non-fossil C) to better apportion source contributions and effectively design cost-effective measures for PM abatement.

\section{Supplementary material related to this article is available online at: http://www.atmos-chem-phys.net/13/ 6185/2013/acp-13-6185-2013-supplement.pdf.}

Acknowledgements. This study was supported by the Ministry of Agriculture, Food and the Environment of Spain, the Ministry of Economy and Competitivity (MINECO) of Spain and FEDER funds under the projects VAMOS (CGL2010-19464/CLI), PRISMA (CGL2012-39623-C02-01), GRACCIE (CSD 200700067), POLLINDUST (CGL2011-26259) and UHU (CGL201128025); and by AGAUR-Generalitat de Catalunya (2009 SGR 00008) and LIFE + AIRUSE (LIFE11-ENV/ES/000584). The Montseny site forms part of the ACTRIS network (European Union Seventh Framework Programme (FP7/2007-2013) project no. 262254), formerly EUSAAR (EUSAAR R113-CT-2006-026140). Funding was also received for the Andalucía sites from projects 2007-RNM027329 and 2011-RNM7800 (Department of Innovation Science and Enterprise, Andalusia Autonomous Government) M. C. Minguillón was funded by the JAE-Doc CSIC programme, co-funded by the European Social Fund (ESF).

Edited by: N. Mihalopoulos

\section{References}

Aldabe, J., Elustondo, D, Santamaría, C., Lasheras, E., Pandolfi, M., Alastuey, A., Querol, X., and Santamaría, J. M.: Chemical characterisation and source apportionment of $\mathrm{PM}_{2.5}$ and $\mathrm{PM}_{10}$ at rural, urban and traffic sites in Navarra (North of Spain), Atmos. Res., 102, 191-205, 2011.

Alves, C. Vicente, A., Pio, C. Kiss, G., Hoffer, A., Decesari S., Prevôt A. S. H., Minguillón, M. C., Querol, X., Hillamo, R., Spindler G., and Swietlicki E.: Organic compounds in aerosols from selected European sites e Biogenic versus anthropogenic sources, Atmos. Environ., 59, 243-255, 2012.

Arhami, M., Kuhn, T., Fine, P. M., Delfino, R. J., and Sioutas, C.: Effects of sampling artifacts and operating parameters on the performance of a semicontinuous particulate elemental carbon/organic carbon monitor, Environ. Sci. Technol., 40, 945954, 2006.

Arnott, W. P., Moosmüller, H., Sheridan, P. J., Ogren, J. A., Raspet, R., Slaton, W. V., Hand, J. L., Kreidenweis, S. M., and Collett Jr., J. L.: Photoacoustic and Filter-Based Ambient Aerosol Light Absorption Measurements: Instrument Comparisons and the Role of Relative Humidity, J. Geophys. Res., 108, 4034, doi:10.1029/2002JD002165, 2003.

Arnott, W. P., Hamasha, K., Moosmüller, H., Sheridan, P. J., and Ogren, J. A.: Towards Aerosol Light Absorption Measurements 
with a 7-wavelength Aethalometer: Evaluation with a Photoacoustic Instrument and 3 wavelength Nephelometer, Aerosol Sci. Tech., 39, 17-29, 2005.

Bae, M.-S., Schauer, J. J., DeMinter, J. T., Turner, J. R., Smith, D., and Cary, R. A.: Validation of a semi-continuous instrument for elemental carbon and organic carbon using a thermal-optical method Atmos. Environ. 38, 2885-2893, 2004.

Bahreini, R., Middlebrook, A. M., de Gouw, J. A., Warneke, C., Trainer, M., Brock, H., Stark, C. A., Brown, S. S., Dube, W. P., Gilman, J. B., Hall, K., Holloway, V., Kuster, W. C., Perring, A. E., Prevot, A. S. H., Schwarz, J. P., Spackman, J. R., Szidat, S., Wagner, N. L., Weber, R. J., Zotter, P., and Parrish D. D.: Gasoline emissions dominate over diesel in formation of secondary organic aerosol mass, Geophys. Res. Lett., 39, L06805, doi:10.1029/2011GL050718, 2012.

Barnard, J. C., Volkamer, R., and Kassianov, E. I.: Estimation of the mass absorption cross 15 section of the organic carbon component of aerosols in the Mexico City Metropolitan Area, Atmos. Chem. Phys., 8, 6665-6679, doi:10.5194/acp-8-6665-2008, 2008.

Birch, M. E. and Cary, R. A.: Elemental carbon-based method for monitoring occupational exposures to particulate diesel exhaust, Aerosol Sci. Technol., 25, 221-241, 1996.

Bond, T. C. and Bergstrom, R. W.: Light absorption by carbonaceous particles: An investigative review, Aerosol Sci. Technol., 40, 27-67, doi:10.1080/02786820500421,521, 2006.

Bond, T. C., Anderson, T. L., and Campbell, D.: Calibration and intercomparison of filter-based measurements of visible light absorption by aerosols, Aerosol Sci. Technol., 30, 582-600, 1999.

Brunekreef, B., Janssen, N. A., de Hartog, J., Harssema, H., Knape, M., and van Vliet P.: Air pollution from truck traffic and lung function in children living near motorways, Epidemiology, 8, 298-303, 1997.

Carslaw, D. C.: The openair manual - open-source tools for analysing air pollution data, Manual for version 0.7-0, King's College London, UK, 2012.

Carslaw, D. C. and Ropkins, K.: Openair - an R package for air quality data analysis, Environ. Modell. Softw., 27-28, 52-61, 2012.

Cavalli, F., Viana, M., Yttri, K. E., Genberg, J., and Putaud, J.-P.: Toward a standardised thermal-optical protocol for measuring atmospheric organic and elemental carbon: the EUSAAR protocol, Atmos. Meas. Tech., 3, 79-89, doi:10.5194/amt-3-79-2010, 2010.

Chow, J. C., Watson, J. G., Pritchett, L. C., Pierson, W. R., Frazier, C. A., and Purcell, R. G.: The DRI thermal optical reflectance carbon analysis system - description, evaluation and applications in United-States air-quality studies, Atmos. Environ., 27, 11851201, 1993.

Chow, J. C., Watson, J. G., Crow, D., Lowenthal, D. H., and Merrifield, T.: Comparison of IMPROVE and NIOSH carbon measurements, Aerosol Sci. Technol., 34, 23-34, 2001.

Chow, J. C., Watson, J. G., Chen, L. W., Arnott, W. P., Moosmuller, H., and Fung, K.: Equivalence of elemental carbon by thermal/optical reflectance and transmittance with different temperature protocols, Environ. Sci. Technol., 38, 4414-4422, 2004.

Chow, J. C., Watson, J. G., Doraiswamy, P., Chen, L.-W. A., Sodeman, D. A., Lowenthal, D. H., Park, K., Arnott, W. P., and Motallebi, N.: Aerosol light absorption, black carbon, and elemental carbon at the Fresno Supersite, California, Atmos. Res. 93, 874887, 2009.

Chow, J. C., Watson, J. G., Lowenthal, D. H., Chen, L. W. A., and Motallebi, N.: Black and organic carbon emission inventories: Review and application to California, J. Air Waste Manage., 60, 497-507, 2010a.

Chow, J. C., Watson, J. G., Chen, L.-W. A., Rice, J., and Frank, N. H.: Quantification of $\mathrm{PM}_{2.5}$ organic carbon sampling artifacts in US networks, Atmos. Chem. Phys., 10, 5223-5239, doi:10.5194/acp-10-5223-2010, 2010b.

Conny, J. M., Klinedinst, D. B., Wight, S. A., and Paulsen, J. L.: Optimizing thermal-optical methods for measuring atmospheric elemental (black) carbon: A response surface study, Aerosol Sci. Technol., 37, 703-723, 2003.

Cusack, M., Alastuey, A., Perez, N., Pey, J., and Querol, X.: Trends of particulate matter $\left(\mathrm{PM}_{2.5}\right)$ and chemical composition at a regional background site in the Western Mediterranean over the last nine years (2002-2010), Atmos. Chem. Phys., 12, 8341-8357, doi:10.5194/acp-12-8341-2012, 2012.

El Haddad, I., Marchand, N., Dron, J., Temime-Roussel, B., Quivet, E., Wortham, H., Jaffrezo, J. L., Baduel, C., Voisin, D., Besombes, J. L., and Gille, G.: Comprehensive primary particulate organic characterization of vehicular exhaust emissions in France, Atmos. Environ., 43, 6190-6198, 2009.

Fernández-Camacho, R., Rodríguez, S., de la Rosa, J., Sánchez de la Campa, A., Viana, M. M., Alastuey, A., and Querol, X.: Ultrafine particle formation in the inland sea breeze airflow in Southwest Europe, Atmos. Chem. Phys., 10, 9615-9630, doi:10.5194/acp10-9615-2010, 2010.

Fine, P. M., Cass, G. R., and Simoneit, B. R. T.: Chemical characterization of fine particle emissions from the fireplace combustion of wood types grown in the Midwestern and Western United States, Environ. Eng. Sci., 21, 387-409, 2004.

Fuzzi, S., Andreae, M. O., Huebert, B. J., Kulmala, M., Bond, T. C., Boy, M., Doherty, S. J., Guenther, A., Kanakidou, M., Kawamura, K.,Kerminen,V. M., Lohmann, U., Russell, L. M., and Poschl, U. Critical Assessment of the Current State of Scientific Knowledge, Terminology, and Research Needs Concerning the role of Organic Aerosols in the 1 Atmosphere, Climate, and Global Change, Atmos. Chem. Phys., 6, 2017-2038, doi:10.5194/acp-6-2017-2006, 2006.

GAW/WMO: Position of the GAW Scientific Advisory Group on the use of Black Carbon terminology, GAW/WMO SAG AEROSOL, 2011.

Gonçalves, C., Alves, C., Evtyugina, M., Mirante, F., Pio, C., Caseiro, A., Schmidl, C., Bauer, H., and Carvalho, F.: Characterisation of $\mathrm{PM}_{10}$ emissions from woodstove combustion of common woods grown in Portugal, Atmos. Environ., 44, 4474-4480, 2010.

Grivas, G., Cheristanidis, S., and Chaloulakou, A.: Elemental and organic carbon in the urban environment of Athens. Seasonal and diurnal variations and estimates of secondary organic carbon, Sci. Total Environ., 414, 535-545, 2012.

Hansen, A. D. A., Rosen, H., and Novakov, T.: The Aethalometer-an Instrument or the Realtime Measurement of Optical Absorption by Aerosol Particles, Sci. Total Environ., 36, 191-196, 1984.

He, X., Li, C. C., Lau, A. k. H., Deng, Z. Z., Mao, J. T., Wang, M. H., and Liu, X. Y.: An intensive study of aerosol optical properties in Beijing urban area, Atmos. Chem. Phys., 9, 8903-8915, 
doi:10.5194/acp-9-8903-2009, 2009.

Hollander, M. and Wolfe, D. A.: Nonparametric statistical methods, 2nd Edn., New York, John Wiley \& Sons, 421-423, 1999.

Jimenez, J. L., Canagaratna, M. R., Donahue, N. M., Prevot, A. S. H., Zhang, Q., Kroll, J. H., DeCarlo, P. F., Allan, J. D., Coe, H., Ng, N. L., Aiken, A. C., Docherty, K. S., Ulbrich, I. M., Grieshop, A. P., Robinson, A. L., Duplissy, J., Smith, J. D., Wilson, K. R., Lanz, V. A., Hueglin, C., Sun, Y. L., Tian, J., Laaksonen, A., Raatikainen, T., Rautiainen, J., Vaattovaara, P., Ehn, M., Kulmala, M., Tomlinson, J. M., Collins, D. R., Cubison, M. J., Dunlea, E. J., Huffman, J. A., Onasch, T. B., Alfarra, M. R., Williams, P. I., Bower, K., Kondo, Y., Schneider, J., Drewnick, F., Borrmann, S., Weimer, S., Demerjian, K., Salcedo, D., Cottrell, L., Griffin, R., Takami, A., Miyoshi, T., Hatakeyama, S., Shimono, A., Sun, J. Y., Zhang, Y. M., Dzepina, K., Kimmel, J. R., Sueper, D., Jayne, J. T., Herndon, S. C., Trimborn, A. M., Williams, L. R., Wood, E. C., Middlebrook, A. M., Kolb, C. E., Baltensperger, U., and Worsnop, D. R.: Evolution of organic aerosols in the atmosphere, Science, 326, 1525-1529, 2009.

Kanakidou, M., Seinfeld, J. H., Pandis, S. N., Barnes, I., Dentener, F. J., Facchini, M. C., Van Dingenen, R., Ervens, B., Nenes, A., Nielsen, C. J., Swietlicki, E., Putaud, J. P., Balkanski, Y., Fuzzi, S., Horth, J., Moortgat, G. K., Winterhalter, R., Myhre, C. E. L., Tsigaridis, K., Vignati, E., Stephanou, E. G., and Wilson, J.: Organic aerosol and global climate modelling: a review, Atmos. Chem. Phys., 5, 1053-1123, doi:10.5194/acp-5-1053-2005, 2005.

Karanasiou, A., Diapouli, E., Cavalli, F., Eleftheriadis, K., Viana, M., Alastuey, A., Querol, X., and Reche, C.: On the quantification of atmospheric carbonate carbon by thermal/optical analysis protocols, Atmos. Meas. Tech., 4, 2409-2419, doi:10.5194/amt4-2409-2011, 2011.

Koulouri, E., Saarikoski, S., Theodosi, C., Markaki, Z., Gerasopoulos, E., Kouvarakis, G., Mäkelä, T., Hillamo, R., and Mihalopoulos, N.: Chemical composition and sources of fine and coarse aerosol particles in the Eastern Mediterranean, Atmos. Environ., 42, 6542-6550, 2008.

Kulmala, M., Asmi, A., Lappalainen, H. K., Baltensperger, U., Brenguier, J.-L., Facchini, M. C., Hansson, H.-C., Hov, Ø., O'Dowd, C. D., Pöschl, U., Wiedensohler, A., Boers, R., Boucher, O., de Leeuw, G., Denier van der Gon, H. A. C., Feichter, J., Krejci, R., Laj, P., Lihavainen, H., Lohmann, U., McFiggans, G., Mentel, T., Pilinis, C., Riipinen, I., Schulz, M., Stohl, A., Swietlicki, E., Vignati, E., Alves, C., Amann, M., Ammann, M., Arabas, S., Artaxo, P., Baars, H., Beddows, D. C. S., Bergström, R., Beukes, J. P., Bilde, M., Burkhart, J. F., Canonaco, F., Clegg, S. L., Coe, H., Crumeyrolle, S., D'Anna, B., Decesari, S., Gilardoni, S., Fischer, M., Fjaeraa, A. M., Fountoukis, C., George, C., Gomes, L., Halloran, P., Hamburger, T., Harrison, R. M., Herrmann, H., Hoffmann, T., Hoose, C., Hu, M., Hyvärinen, A., Hõrrak, U., Iinuma, Y., Iversen, T., Josipovic, M., Kanakidou, M., Kiendler-Scharr, A., Kirkevåg, A., Kiss, G., Klimont, Z., Kolmonen, P., Komppula, M., Kristjánsson, J.-E., Laakso, L., Laaksonen, A., Labonnote, L., Lanz, V. A., Lehtinen, K. E. J., Rizzo, L. V., Makkonen, R., Manninen, H. E., McMeeking, G., Merikanto, J., Minikin, A., Mirme, S., Morgan, W. T., Nemitz, E., O’Donnell, D., Panwar, T. S., Pawlowska, H., Petzold, A., Pienaar, J. J., Pio, C., Plass-Duelmer, C., Prévôt, A. S. H., Pryor, S., Reddington, C. L., Roberts, G., Rosenfeld, D.,
Schwarz, J., Seland, Ø., Sellegri, K., Shen, X. J., Shiraiwa, M., Siebert, H., Sierau, B., Simpson, D., Sun, J. Y., Topping, D., Tunved, P., Vaattovaara, P., Vakkari, V., Veefkind, J. P., Visschedijk, A., Vuollekoski, H., Vuolo, R., Wehner, B., Wildt, J., Woodward, S., Worsnop, D. R., van Zadelhoff, G.-J., Zardini, A. A., Zhang, K., van Zyl, P. G., Kerminen, V.-M., S Carslaw, K., and Pandis, S. N.: General overview: European Integrated project on Aerosol Cloud Climate and Air Quality interactions (EUCAARI) - integrating aerosol research from nano to global scales, Atmos. Chem. Phys., 11, 13061-13143, doi:10.5194/acp11-13061-2011, 2011.

Larssen, S., Sluyter, R., and Helmis, C.: Criteria for EUROAIRNET. The EEA Air Quality and Information Network. Technical Report No. 12. European Environment Agency, Copenhagen, http://www.eea.europa.eu/publications/TEC12, 1999.

Mader, B. T., Flagan, R. C., and Seinfeld, J. H.: Sampling atmospheric carbonaceous aerosols using a particle trap impactor/denuder sampler, Environ. Sci. Technol., 35, 4857-4867, 2001.

Maenhaut, W., Cafmeyer, J., Chi, X., and Schwarz, J.: Assessment of artefacts in filter collections for carbonaceous aerosols and the particulate mass, J. Aerosol Sci., 32, S673-S674, 2001.

Maenhaut, W., Claeys, M., Vercauteren, J., and Roekens, E.: Comparison of different operational parameters for thermal-optical EC/OC measurements of filter samples from Flanders, Belgium, European Aerosol Conference 2012 abstracts, http://www. eac2012.com/EAC2012Book/files/235.pdf, 2012.

Mauderly, J. L. and Chow, J. C.: Health effects of organic aerosols, Inhal. Toxicol., 20, 257-288, 2008.

Minguillón, M. C., Perron, N., Querol, X., Szidat, S., Fahrni, S. M., Alastuey, A., Jimenez, J. L., Mohr, C., Ortega, A. M., Day, D. A., Lanz, V. A., Wacker, L., Reche, C., Cusack, M., Amato, F., Kiss, G., Hoffer, A., Decesari, S., Moretti, F., Hillamo, R., Teinilä, K., Seco, R., Peñuelas, J., Metzger, A., Schallhart, S., Müller, M., Hansel, A., Burkhart, J. F., Baltensperger, U., and Prévôt, A. S. H.: Fossil versus contemporary sources of fine elemental and organic carbonaceous particulate matter during the DAURE campaign in Northeast Spain, Atmos. Chem. Phys., 11, 12067-12084, doi:10.5194/acp-11-12067-2011, 2011.

Mohr, C., Decarlo, F., Heringa, M. F., Chirico, R., Slowik, J. G., Richter, R., Reche, R., Alastuey, A., Querol, X., Seco, R., Peñuelas, J., Jiménez, J. L., Crippa, M., Zimmermann, R., Baltensperger, U., Prévôt, A. S. H.: Identification and quantification of organic aerosol from cooking and other sources in Barcelona using aerosol mass spectrometer data, Atmos. Chem. Phys., 12, 1649-1665, doi:10.5194/acp-12-1649-2012, 2012.

Müller, T., Henzing, J. S., de Leeuw, G., Wiedensohler, A., Alastuey, A., Angelov, H., Biz-jak, M., Collaud Coen, M., Engström, J. E., Gruening, C., Hillamo, R., Hoffer, A., Imre, K., Ivanow, P., Jennings, G., Sun, J. Y., Kalivitis, N., Karlsson, H., Komppula, M., Laj, P., Li, S.-M., Lunder, C., Marinoni, A., Martins dos Santos, S., Moerman, M., Nowak, A., Ogren, J. A., Petzold, A., Pichon, J. M., Rodriquez, S., Sharma, S., Sheridan, P. J., Teinilä, K., Tuch, T., Viana, M., Virkkula, A., Weingartner, E., Wilhelm, R., and Wang, Y. Q.: Characterization and intercomparison of aerosol absorption photometers: result of two intercomparison workshops, Atmos. Meas. Tech., 4, 245-268, doi:10.5194/amt-4-245-2011, 2011. 
Novakov, T., Andreae, M. O., Gabriel, R., Kirchstetter, T. W., Mayol-Bracero, O. L., and Ramanathan, V.: Origin of carbonaceous aerosols over the tropical Indian Ocean: Biomass burning or fossil fuels?, Geophys. Res. Lett., 27, 4061-4064, 2000.

Pérez, N., Pey, J., Querol, X., Alastuey, A., López, J. M., and Viana, M.: Partitioning of major and trace components in $\mathrm{PM}_{10}-\mathrm{PM}_{2.5^{-}}$ $\mathrm{PM}_{1}$ at an urban site in Southern Europe, Atmos. Environ., 42/8, 1677-1691, 2008.

Petzold, A. and Schönlinner, M.: Multi-angle absorption photometry - a new method for the measurement of aerosol light absorption and atmospheric black carbon, J. Aerosol Sci., 35, 421-441, 2004.

Pey, J., Pérez, N., Querol, X., Alastuey, A., Cusack, M., and Reche, C.: Intense winter atmospheric pollution episodes affecting the Western Mediterranean, Sci. Total Environ., 408, 1951-1959, 2010.

Phuah, C. H., Peterson, M. R., Richards, M. H., Turner, J. H., and Dillner, A. M.: A Temperature Calibration Procedure for the Sunset Laboratory Carbon Aerosol Analysis Lab Instrument, Aerosol Sci. Tech., 43, 1013-1021, 2009.

Pio, C. A., Castro, L. M., and Ramos, M. O.: Differentiated determination of organic and elemental carbon in atmospheric aerosol particles by thermal.optics method, in: Proceedings of the Sixth European Symposium: Physico-Chemical Behaviour of Atmospheric Pollutants, edited by: Angeletti, G. and Restelli, G., Report EUR 15609/2 EN, European Commission, 706-711, 1994.

Pio, C. A., Legrand, M., Oliveira, T., Afonso, J., Santos, C., Caseiro, A., Fialho, P., Barata, F., Puxbaum, H., Sanchez-Ochoa, A., Kasper-Giebl, A., Gelencsér, A., Preunkert, S., and Schock, M.: Climatology of aerosol composition (organic versus inorganic) at nonurban sites on a west-east transect across Europe. J. Geophys. Res., 112, D23S02, doi:10.1029/2006JD008038, 2007.

Pio, C. A., Cerqueira, M., Harrison, R. M., Nunes, T., Mirante, F., Alves, C., Oliveira, C., Sanchez de la Campa, A., Artiñano, B., and Matos, M.: OC/EC Ratio Observations in Europe: Rethinking the approach for apportionment between primary and secondary organic carbon, Atmos. Environ., 45, 6121-6132, 2011.

Platt, S. M., El Haddad, I., Zardini, A. A., Clairotte, M., Astorga, C., Wolf, R., Slowik, J. G., Temime-Roussel, B., Marchand, N., Ježek, I., Drinovec, L., Močnik, G., Möhler, O., Richter, R., Barmet, P., Bianchi, F., Baltensperger, U., and Prévôt, A. S. H.: Secondary organic aerosol formation from gasoline vehicle emissions in a new mobile environmental reaction chamber, Atmos. Chem. Phys. Discuss., 12, 28343-28383, doi:10.5194/acpd-1228343-2012, 2012.

Plaza, J., Artíñano, B., Salvador, P., Gómez-Moreno, F. J., Pujadas, M., and Pio C. A.: Short-term SOA estimations with a modified OC/EC primary ratio method at a suburban site in Madrid (Spain), Atmos. Environ., 45, 2496-2506, 2011.

Putaud, J.-P., Van Dingenen, R., Alastuey, A., Bauer, H., Birmili, W., Cyrys, J., Flentje, H., Fuzzi, S., Gehrig, R., Hansson, H. C., Harrison, R. M., Herrmann, H., Hitzenberger, R., Hüglin, C., Jones, A. M., Kasper-Giebl, A., Kiss, G., Kousa, A., Kuhlbusch, T. A. J., Löschau, G., Maenhaut, W., Molnar, A., Moreno, T., Pekkanen, J., Perrino, C., Pitz, M., Puxbaum, H., Querol, X., Rodriguez, S., Salma, I., Schwarz, J., Smolik, J., Schneider, J., Spindler, G., ten Brink, H., Tursic, J., Viana, M., Wiedensohler, A., and Raes, F.: A European aerosol phenomenology - 3: Phys- ical and chemical characteristics of particulate matter from 60 rural, urban, and kerbside sites across Europe. Atmos. Environ., 44, 10, 1308-1320, 2010.

Querol, X, Alastuey, A., Moreno, T., Viana, M. M., Castillo, S., Pey, J., Rodríguez, S., Artiñano, B., Salvador, P., Sánchez, M., Garcia Dos Santos, S., Herce Garraleta, M. D., Fernandez-Patier, R., Moreno-Grau, S., Minguillón, M. C., Monfort, E., Sanz, M. J., Palomo-Marín, R., Pinilla-Gil, E., Cuevas, E., De la Rosa, J., and Sanchez de la Campa, A.: Spatial and temporal variations in airborne particulate matter $\left(\mathrm{PM}_{10}\right.$ and $\left.\mathrm{PM}_{2.5}\right)$ across Spain 1999-2005, Atmos. Environ. 42, 3964-3979, 2008.

Ramana, M. V., Ramanathan, V., Feng, Y., Yoon, S. C., Kim, S. W., Carmichael, G. R., and Schauer, J. J.: Warming influenced by the ratio of black carbon to sulphate and the black-carbon source, Nature Geosci. 3, 542-545, 2010.

Ramanathan, V. and Carmichael, G.: Global and regional climate changes due to black carbon, Nature Geosci., 1, 221-227, 2008.

Reche, C., Querol, X., Alastuey, A., Viana, M., Pey, J., Moreno, T., Rodríguez, S., González, Y., Fernández-Camacho, R., de la Rosa, J., Dall'Osto, M., Prévôt, A. S. H., Hueglin, C., Harrison, R. M., and Quincey, P.: New considerations for PM, Black Carbon and particle number concentration for air quality monitoring across different European cities, Atmos. Chem. Phys., 11, 6207-6227, doi:10.5194/acp-11-6207-2011, 2011.

Reche, C., Viana, M., Amato, F., Alastuey, A., Moreno, T., Hillamo, R., Teinilä, K., Saarnio, K., Seco, R., Peñuelas, J., Mohr, C., Prévôt, A. S. H., and Querol, X.: Biomass burning contributions to urban aerosols in a coastal Mediterranean City, Sci. Total Environ., 175-190, 2012.

Robinson, A. L., Donahue, N. M., Shrivastava, M. K., Weitkamp, E. A., Sage, A. M., Grieshop, A. P., Lane, T. E., Pierce, J. R., and Pandis, S. N.: Rethinking organic aerosols: Semivolatile emissions and photochemical aging, Science 315, 1259-1262, 2007.

Salmi, T., Määttä, A., Anttila, P., Ruoho-Airola, T., and Amnell, T.: Detecting trends of annual values of atmospheric pollutants by the Mann-Kendall test and Sen's slope estimates - the Excel template application MAKESENS. In Publications on Air Quality No. 31 (ed. Finnish Meteorological Institute), p. 35, Finnish Meteorological Institute, 2002.

Schauer, J. J., Mader, B. T., DeMinter, J. T., Heidemann, G., Bae, M. S., Seinfeld, J. H., Flagan, R, C., Cary, R. A., Smith, D., Huebert, B. J., Bertram, T., Howell, S., Kline, J. T., Quinn, P., Bates, T., Turpin, B., Lim, H. J., Yu, J. Z., Yang, H., and Keywood, M. D.: ACE-Asia intercomparison of a thermal-optical method for the determination of particle phase organic and elemental carbon, Environ. Sci. Technol., 37, 993-1001, 2003.

Schmid, H., Laskus, L., Abraham, H. J., Baltensperger, U., Lavanchy, V., Bizjak, M., Burba, P., Cachier, H., Crow, D., Chow, J., Gnauk, T., Even, A., ten Brink, H. M., Giesen, K. P., Hitzenberger, R., Hueglin, C., Maenhaut, W., Pio, C., Carvalho, A., Putaud, J. P., Toom-Sauntry, D., and Puxbaum, H.: Results of the 19 "carbon conference" international aerosol carbon round robin test stage I, Atmos. Environ., 20, 2111-2121, 2001.

Seco, R., Peñuelas, J., Filella, I., Llusià, J., Molowny-Horas, R., Schallhart, S., Metzger, A., Müller, M., and Hansel, A.: Contrasting winter and summer VOC mixing ratios at a forest site in the Western Mediterranean Basin: the effect of local biogenic emissions, Atmos. Chem. Phys., 11, 13161-13179, doi:10.5194/acp11-13161-2011, 2011. 
Sen, P. K.: Estimates of regression coefficient based on kendall's tau, J. Am. Stat. Assoc., 63, 1379-1389, 1968.

Shindell, D., Kuylenstierna, J. C. I., Vignati, E., van Dingenen, R., Amann, M., Klimont, Z., Anenberg, S. C., Muller, N., JanssensMaenhout, G., Raes, F., Schwartz, J., Faluvegi, G., Pozzoli, L., Kupiainen, K., Höglund-Isaksson, L., Emberson, L., Streets, D., Ramanathan, V., Hicks, K., Oanh, N. T. K., Milly, G., Williams, M. L., Demkine, V., and Fowler, D.: Simultaneously mitigating near-term climate change and improving human health and food security, Science, 335, 183-189, doi:10.1126/science.1210026, 2012.

Spindler, G., Brüggemann, E., Gnauk, T., Grüner, A., Müller, K., and Herrmann, H.: A four-year size-segregated characterization study of particles $\mathrm{PM}_{10}, \mathrm{PM}_{2.5}$ and PM1 depending on air mass origin at Melpitz, Atmos. Environ., 44, 164-173, 2010.

Subramanian, R., Khlystov, A. Y., Cabada, J. C., and Robinson, A. L.: Positive and negative artifacts in particulate organic carbon measurements with denuded and undenuded sampler configurations, Aerosol Sci. Technol., 38, 27-48, 2004.

Subramanian, R., Khlystov, A. Y., and Robinson, A. L.: Effect of peak inert-mode temperature on elemental carbon measured using thermal optical analysis, Aerosol Sci. Technol., 40, 763-780, 2006.

Szidat, S., Prevot, A. S. H., Sandradewi, J., Alfarra, M. R., Synal, H. A., Wacker, L., and Baltensperger, U.: Dominant impact of residential wood burning on particulate matter in Alpine valleys during winter, Geophys. Res. Lett., 34, L05820, doi:10.1029/2006GL028325, 2007.

Theil, H.: A rank invariant method of linear and polynomial regression analysis, i, ii, iii, Proceedings of the Koninklijke Nederlandse Akademie Wetenschappen, Series A - Math. Sci., 53, 386-392, 521-525, 1397-1412, 123, 1950.

Turpin, B. J., Saxena, P., and Andrews, E.: Measuring and simulating particulate organics in the atmosphere: problems and prospects, Atmos. Environ., 34, 2983-3013, 2000.

Verma, V., Ning, Z., Cho, A. K. Schauer, J. J., Shafer, M. M., and Sioutas, C.: Redox activity of urban quasi-ultrafine particles from primary and secondary sources, Atmos. Environ., 43 6360-6368, 2009.

Viana, M., Chi, X., Maenhaut, W., Querol, X., Alastuey, A., Mikuska, P., and Vecera, Z.: Organic and elemental carbon concentrations in carbonaceous aerosols during summer and winter sampling campaigns in Barcelona, Spain, Atmos. Environ., 40, 2180-2193, 2006.

Viana, M., Maenhaut, W., ten Brink, H. M., Chi, X., Weijers, X., Querol, X., Alastuey, X., Mikuska, P., and Vecera, Z.: Comparative analysis of organic and elemental carbon concentrations in carbonaceous aerosols in three European cities, Atmos. Environ. 41, 5972-598, 2007.
Viana, M., Querol, X., Reche, C., Favez, O., Malherbe, L., Ustache, A., Bartonova, A., Liu, H.-Y., and Guerreiro, C.: Particle number (PNC) and black carbon (BC) in EU urban air quality networks. ETC/ACM Technical Paper 2012/6, 2013a.

Viana, M., Reche, C., Amato, F., Alastuey, A., Querol, X., Moreno, T., Lucarelli, F., Nava, S., Cazolai, G., Chiari, M., Rico, M.,: Evidence of biomass burning aerosols in the Barcelona urban environment during winter time, Atmos. Environ. 72, 81-88. $2013 \mathrm{~b}$.

Volkamer, R., Jimenez, J. L., Dzepina, K., Salcedo, D., SanMartini, F. M., Molina, L. T., Worsnop, D. R., and Molina, M. J.: Secondary Organic Aerosol formation from Anthropogenic Air Pollution: Rapid and higher than expected, Geophys. Res. Lett., 33, L17811, doi:10.1029/2006GL026899, 2006.

Wang, Y., Chung, A., and Paulson, S. E.: The effect of metal salts on quantification of elemental and organic carbon in diesel exhaust particles using thermal-optical evolved gas analysis, Atmos. Chem. Phys., 10, 11447-11457, doi:10.5194/acp-1011447-2010, 2010.

WHO 2012: Health effects of black carbon. Janssen, N. A. H., Gerlofs-Nijland, M. E., Lanki, T., Salonen, R. O., Cassee, F., Hoek, G., Fischer, P., Brunekreef, B., and Krzyzanowski, M.: WHO's Regional Office for Europe, Copenhaguen, 86 pp., ISBN 9789289002653, http://www.euro.who.int/__data/assets/pdf_file/ 0004/162535/e96541.pdf, 2012.

WHO 2013: Review of evidence on health aspects of air pollution - REVIHAAP. First Results. WHO's Regional Office for Europe, Copenhaguen, 28 pp., http://www.euro.who.int/__data/ assets/pdf_file/0020/182432/e96762-final.pdf, 2013.

Williams, M. L. and Carslaw, D. C.: New Directions: Science and policy - Out of step on $\mathrm{NO}_{\mathrm{x}}$ and $\mathrm{NO}_{2}$ ?, Atmos. Environ., 45, 3911-3912, 2011.

Yttri, K. E., Aas, W., Bjerke, A., Cape, J. N., Cavalli, F., Ceburnis, D., Dye, C., Emblico, L., Facchini, M. C., Forster, C., Hanssen, J. E., Hansson, H. C., Jennings, S. G., Maenhaut, W., Putaud, J. P., and Tørseth, K.: Elemental and organic carbon in $\mathrm{PM}_{10}$ : a one year measurement campaign within the European Monitoring and Evaluation Programme EMEP, Atmos. Chem. Phys., 7, 5711-5725, doi:10.5194/acp-7-5711-2007, 2007.

Zielinska, B., Sagebiel, J., McDonald, J. D., Whitney, K., and Lawson, D. R.: Emission rates and comparative chemical composition from selected in-use diesel and gasoline fueled vehicles, J. Air Waste Manage. Assoc., 9, 1138-1150, 2004. 